\title{
O SENTIDO DO LUGAR IDENTIDADES LÍQUIDAS
}

Luz Bañón

\begin{tabular}{|c|c|}
\hline 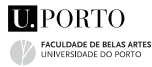 & i2ADS. \\
\hline
\end{tabular}


Esta publicação foi realizada por ocasião da exposição 'O sentido do Lugar - Identidades Liquidas', na Galeria Museológica do Fórum de Ermesinde, nos meses de novembro e dezembro de 2020 , e reúne obras e textos relativos à investigação realizada parcialmente por Luz Bañón durante a estância de mobilidade internacional como investigadora no Instituto e Investigação em Arte, Design e Sociedade, no Porto. A curadoria da exposição é da responsabilidade de Domingos Loureiro.

\section{Título}

O sentido do Lugar - Identidades Líquidas

\section{Coordenação}

Domingos Loureiro (i2ADS/FBA Universidade do Porto)

\section{Comissão Científica}

Victoria Sanchez Giner (AEC/FBBAA Universidad Murcia) Rute Rosas (i2ADS/FBA Universidade do Porto)

Luís Fortunato Lima (FBA Universidade do Porto)

Toni Simó Mullet (AEC/FBBAA Universidad Murcia)

Jesus Segura Cabanero (AEC/FBBAA Universidad Murcia)

\section{Textos}

Domingos Loureiro, Luz Bañón

\section{Edição}

i2ADS - Instituto de Investigação em Arte, Design e Sociedade; i2ads.up.pt

\section{Colaboração}

Câmara Municipal de Valongo

Fórum de Ermesinde

\author{
Apoio Técnico \\ Estela Costa \\ Paulo Oliveira \\ Margarida Dias \\ Design \\ Maxi Gómez \\ julho 2021
}

ISBN: 978-989-9049-11-6

Este trabalho é financiado por fundos nacionais através da FCT - Fundação para a Ciência e a Tecnologia, I.P., no âmbito do projeto «UIDB/04395/2020»

Depósito Legal: MU867-2021

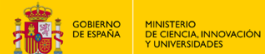

A mobilidade internacional da Investigadora Luz Bañón foi apoiada pelo Ministério de la Cultura y Deporte do Gobierno de España 


\section{Índice}

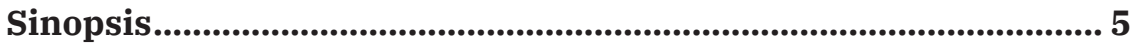

La acción trascendental del espacio y el tiempo............................. 9

\section{Obras}

Discontinuou echo (2020) ............................................................... 18

Serie stereoscopic interventions-Porto (2020) ........................... 20

Stereoscopic Interventions Porto I-Ribeira ..................................20

Stereoscopic Interventions Porto II-São Nicolau ...........................20

Stereoscopic Interventions Porto III-Ponte Luiz I........................ 20

Time space and mutable identities (2019) ................................... 22

Seven seconds (2018) ........................................................................ 24

Serie reflexión temporal (2016-2018) ........................................... 26

Reflexión temporal I - Plaza de las flores (2016)..........................26

Reflexión temporal 2 - Plano de San Francisco (2016) ................27

Reflexión temporal 3- Murcia desde la Catedral (2017).............. 28

Reflexión temporal 4- Plaza de San Pedro (2017).........................2 29

Reflexión temporal 6- Gran Vía Caravaca (2018)........................... 30

Reflexión temporal 7- Caravaca (2018) ........................................... 31

Serie cajas de historia (2016-2020) .............................................. 33

Serie caja de historias I -Plaza Belluga (2016)................................ 33

Serie caja de historias 3 - Jara Carrillo (2016)............................... 35

Serie caja de historias 4 - Plaza de la Cruz (2016) ......................... 37

Serie caja de historias 5 - Casino (2016) ........................................ 39

Serie caja de historias 6 - Glorieta de España ................................ 41

Serie caja de historias 12- Arco na Ribeira Porto ......................... 43

Serie caja de historias 13- Casa Amarella Porto ........................... 45

Serie caja de historias 14- Passeio das Fontainhas Porto........... 47

Serie caja de historias 15- Mercado São Nicolau ........................... 49

Serie registros akáshicos (2016) ............................................... 51

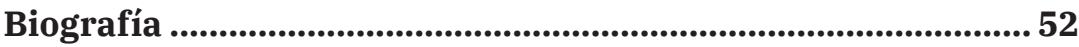




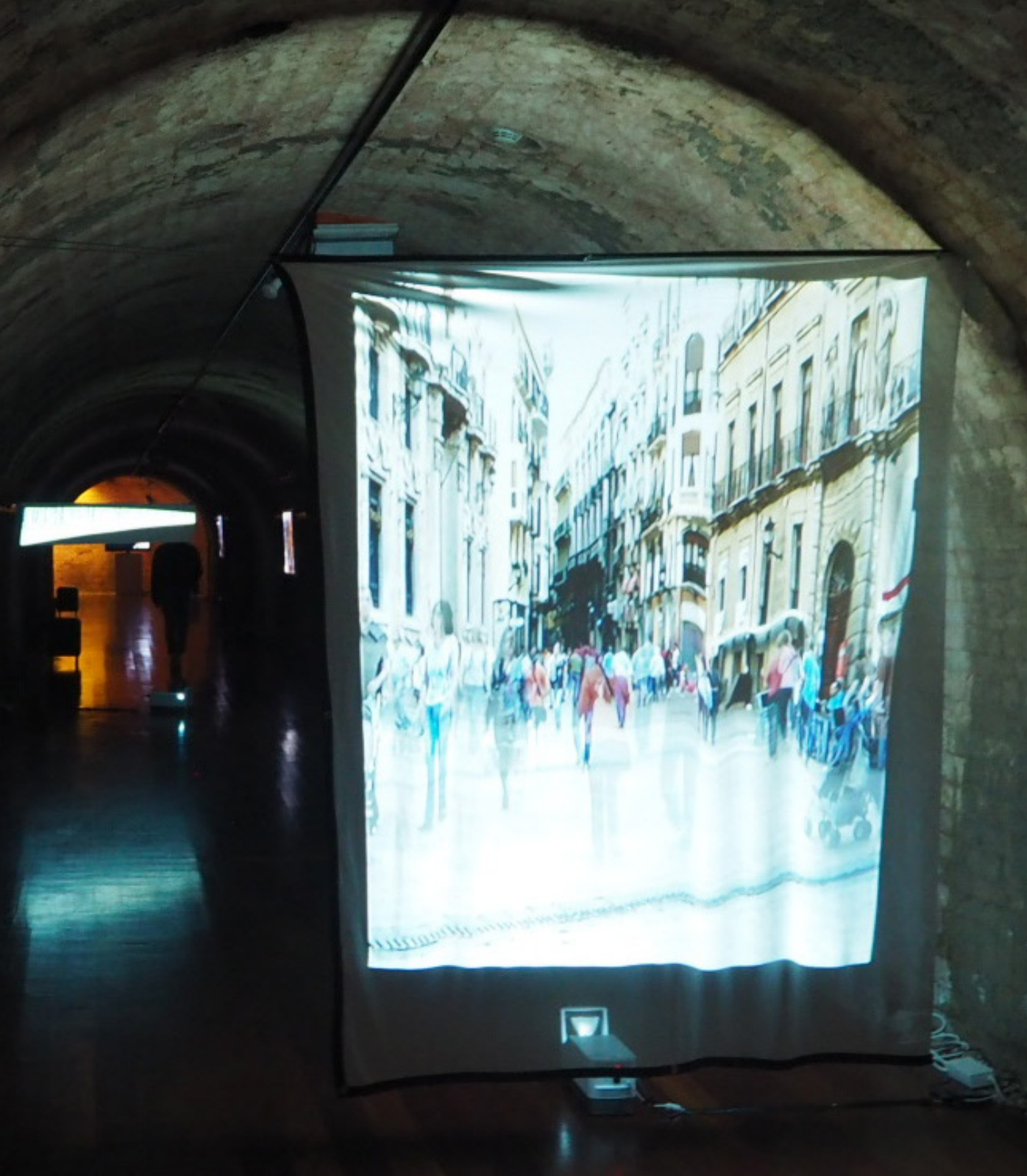




\section{Sinopsis}

El SENTIDO DEL LUGAR. IDENTIDADES LIQUIDAS ofrece una visión alternativa de los lugares contemporáneos, relacionándolos con el comportamiento humano y la transformación de los espacios. Una exposición que aúna videoinstalación y fotografía en busca de una reflexión sobre la influencia de la globalización en la identidad, la diversidad cultural y social humana, así como en la modificación de los espacios. El objeto de este proyecto expositivo es lograr que el espectador se replantee su lugar en el mundo, poniendo en cuestión el ritmo frenético que marca la cadencia de nuestras vidas. Un ritmo marcado por los intereses establecidos por las cartografías del poder dentro de unos parámetros socioeconómicos centrados únicamente en valores como la productividad y el rendimiento.

El lugar está conectado indisolublemente al concepto de tiempo, a los recuerdos, la memoria y las fronteras. Es una unidad tangible y finita del espacio que pueden ser experimentada a través de nuestros sentidos. En los espacios, diferentes tipos de personas, con heterogéneas identidades culturales, físicas y sociales, coexisten cada día. El SENTIDO DEL LUGAR. IDENTIDADES LIQUIDAS es una metáfora de cómo adaptamos constantemente nuestra identidad social como consecuencia de la homogeneización derivada del proceso de globalización, convirtiéndonos en nuevos ciudadanos con identidades líquidas o mutables. Vivimos juntos en ciudades difusas, donde todos estamos influenciados por todos y, al mismo tiempo, todos influimos en todos los demás. A través de la edición fotográfica y de vídeo, los personajes que aparecen en mis obras se desarrollan en entidades separadas que fluyen a diferentes ritmos y como un caleidoscopio que genera nuevas realidades y rompen con la narrativa lineal hegemónica. Unos personajes que parece cruzarse una y otra vez a través de mundos paralelos.

El SENTIDO DEL LUGAR. IDENTIDADES LIQUIDAS pretende generar una atmósfera onírica y sugerente, en la que los espacios se diluyen y los personajes se convierten en estelas de luz y color. Una interpretación de la realidad construida por el hombre, que nos mueve sensorialmente a través de nuevas dimensiones espaciotemporales hacia una nueva realidad social.

\section{Luz Bañón}



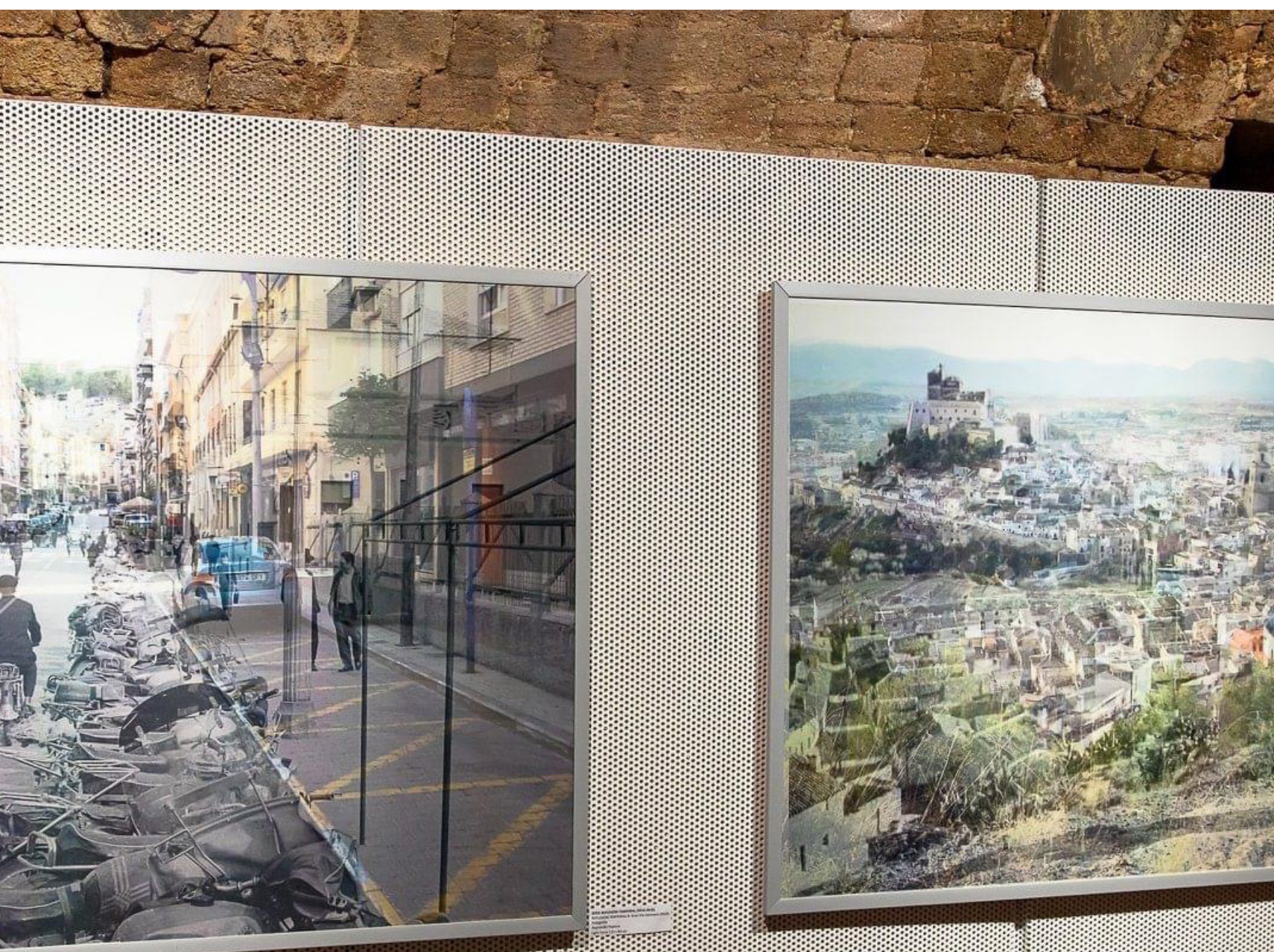

$1 /$

30

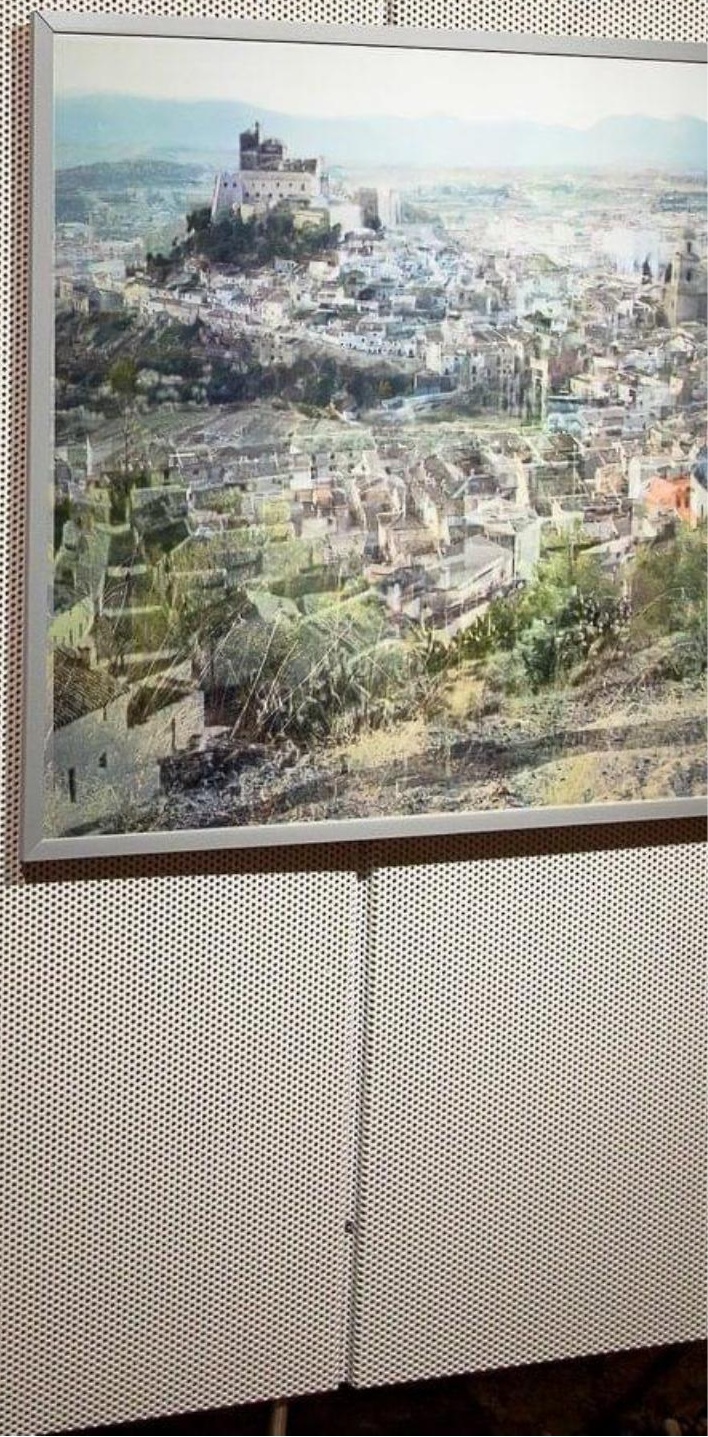




\section{Sinopse}

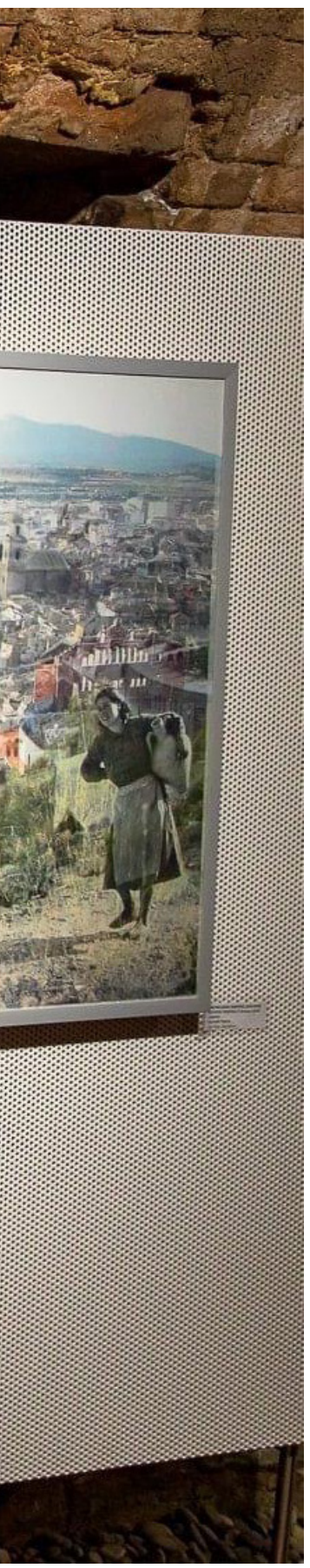

O SENTIDO DE LUGAR. IDENTIDADES LÍQUIDAS oferece uma visão alternativa dos lugares contemporâneos, relacionando-os com o comportamento humano e a transformação dos espaços. Uma exposição que combina video-instalação e fotografia em busca de uma reflexão sobre a influência da globalização na identidade humana, na diversidade cultural e social, bem como na modificação dos espaços. O objetivo deste projeto expositivo é fazer o espectador repensar o seu lugar no mundo, questionando o ritmo frenético que marca a cadência das nossas vidas. Um ritmo marcado pelos interesses estabelecidos pelas cartografias de poder dentro de parâmetros socio-económicos voltados exclusivamente para valores como produtividade e desempenho.

O lugar está intrinsecamente ligado ao conceito de tempo, memórias e fronteiras. É uma unidade de espaço finita e tangível que pode ser experimentada por meio de nossos sentidos. Nos espaços coexistem todos os dias diferentes tipos de pessoas, com identidades culturais, físicas e sociais heterogéneas. O SENTIDO DE LUGAR. IDENTIDADES LÍQUIDAS é uma metáfora de como adaptamos constantemente a nossa identidade social em consequência da homogeneização derivada do processo de globalização, tornandonos novos cidadãos com identidades líquidas ou mutáveis. Vivemos juntos em cidades confusas, onde todos somos influenciados por todos e, ao mesmo tempo, influenciamos todos os outros.

Por meio da edição fotográfica e de vídeo, os personagens que aparecem nas obras se desenvolvem em entidades distintas que fluem em ritmos diferentes e como um caleidoscópio que gera novas realidades e rompe com a narrativa linear hegemónica. Personagens que parecem cruzar-se continuamente em mundos paralelos.

O SENTIDO DE LUGAR. IDENTIDADES LÍQUIDAS pretende gerar uma atmosfera onírica e sugestiva, em que os espaços se diluem e os personagens se tornem rastros de luz e cor.

Uma interpretação da realidade construída pelo homem, que nos move sensorialmente através de novas dimensões espaço-temporais para uma nova realidade social.

Luz Bañón 


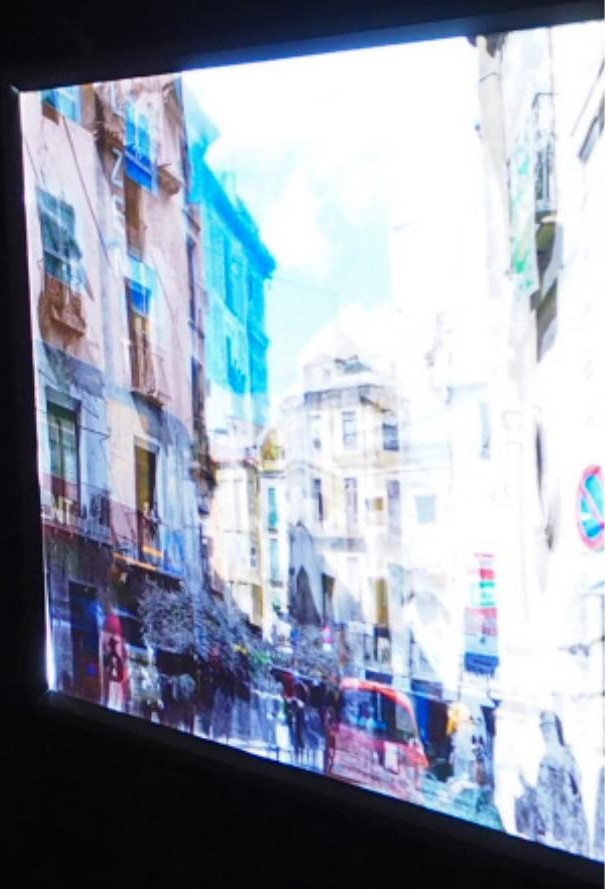




\section{La acción trascendental del espacio y el tiempo}

\section{A ação transcendental do espaço e do tempo}

La propuesta de Luz Bañón de tratar el Sentido del Lugar es un reto de enorme complejidad dada la amplitud del término lugar, capaz de aglutinar nociones de lo concreto, como la determinación geofísica, y conceptos de pura abstracción, a los que se accede por medio de análisis comparativos o de naturaleza conceptual.

Desde el punto de vista de la objetividad, el lugar, parece ser estático y definido, delimitado por coordenadas que podemos cartografiar y a las que podemos acceder consecutivamente usando un GPS, como cuando pensamos en París, Londres, Murcia o Ermesinde.

Sin embargo, cada una de estas coordenadas parece designar algo distinto con cada nuevo punto de vista y cada nuevo observador. El mismo territorio parece diferente con cada nueva mirada, así que pregunto: - ¿Cuántas veces nos hemos dado cuenta de que un espacio que ya conocíamos parece irreconocible en otro momento? Esta transformación parece ser el resultado de la interpretación de sus usuarios, que varía de un individuo a otro. El lugar parece estar afectado por una identidad combinada entre el espacio y los usuarios, impregnada de una naturaleza social y cultural. El lugar es por lo tan-

A proposta de Luz Bañón de tratar o Sentido de Lugar é um desafio de enorme complexidade dada a amplitude da terminologia lugar, capaz de compilar noções de concreto, como determinação geofísica, e conceitos de pura abstração, a que se acedem por análise comparativa ou de natureza conceptual.

Do ponto de vista da objetividade, o lugar, parece ser estático e definido, delimitado por coordenadas que podemos mapear e aceder consecutivamente com recurso a um GPS, como quando pensamos em Paris, Londres, Múrcia ou Ermesinde.

Todavia, cada uma dessas coordenadas parece designar algo distinto a cada nova mirada e a cada novo observador. O mesmo território parece diferente a cada novo olhar, pelo que pergunto: - Quantas vezes nos apercebemos que um espaço que já conhecíamos, parece irreconhecível noutro momento? Esta transformação parece ser o resultado da interpretação dos seus utilizadores, variando de indivíduo para indivíduo. O lugar parece ser afetado por uma identidade combinada entre espaço e utilizadores, impregnado-o de uma natureza 


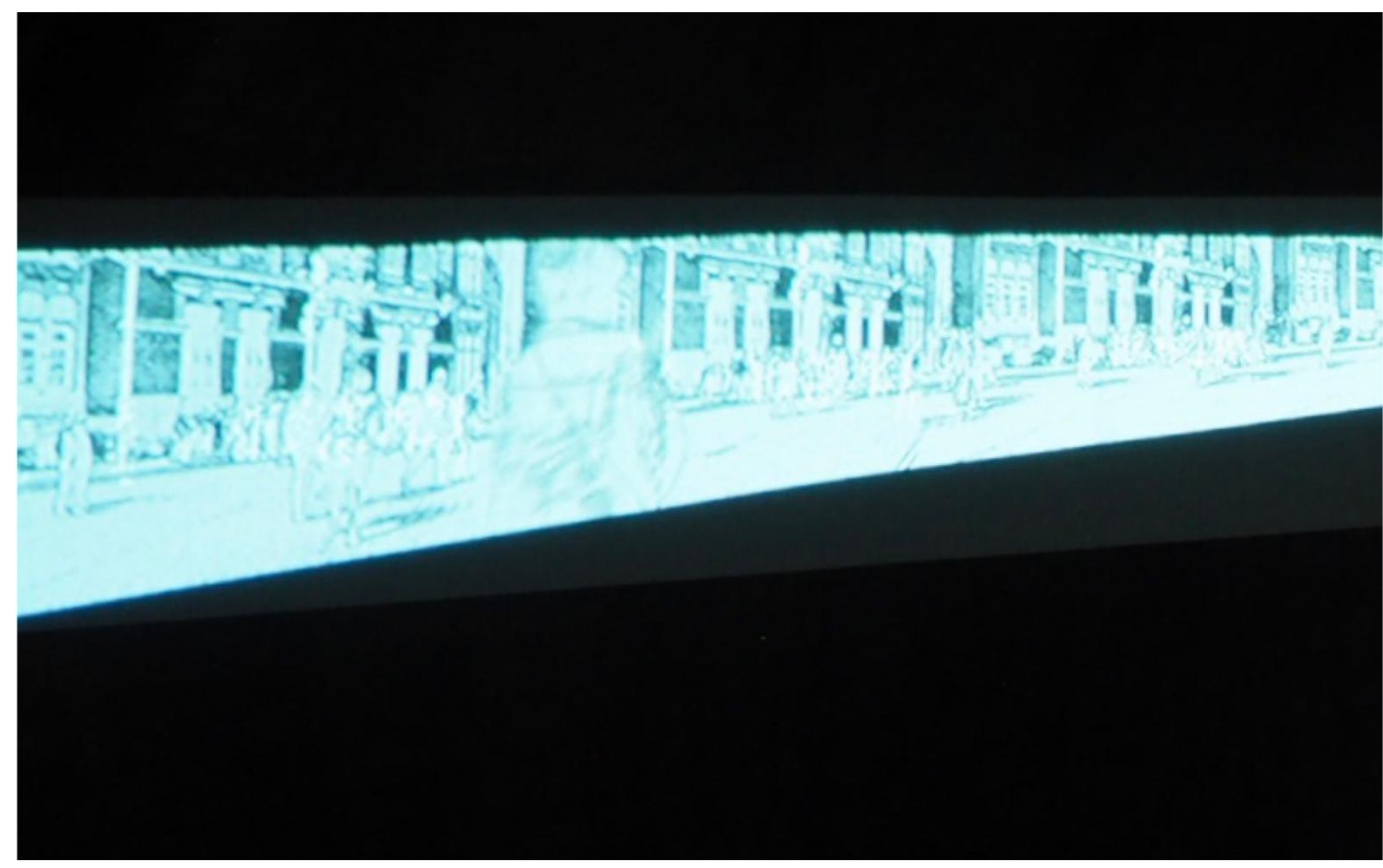

to metamórfico, siendo el tiempo, su principal escultor y alquimista, recordando aquí la perseverancia de António López García, cuando durante años realizó pinturas de lugares como la Gran Vía, a las 6h30, tratando de registrar lo que parecía permanecer estático, pero que obviamente estaba cambiando.

El lugar es entonces, espacio y tiempo! El espacio tiene la garantía de permanencia durante un micro-instante, como sustituto de eventos continuos que alteran y metamorfosean su dimensión estructural. Estos cambios sólo son identificables por comparación, cuando, en un segundo momento, lo relacionamos con un momento anterior. El tiempo, a su vez, es visible cuando se cuenta, o también por comparación entre un antes y un después.

Por lo tanto, el lugar ya no es un espacio. El lugar es una combinación de espacio y tiempo en permanente cambio, en continua transfiguración, que origina consecutivamente la redefinición de la noción de ese territorio. Por lo tanto, el lugar es cuestión de capas, como un reloj en el que cada instante añade una nueva identidad y que varía con cada nuevo aspecto. Tomemos el ejemplo de la definición de lugar que la mayoría de los habitantes y usuarios de Nueva York tienen hasta las 8:45 de la mañana del 11 de septiembre de 2001. Esta definición cambia drásticamente a lo largo de la sucesión de eventos 

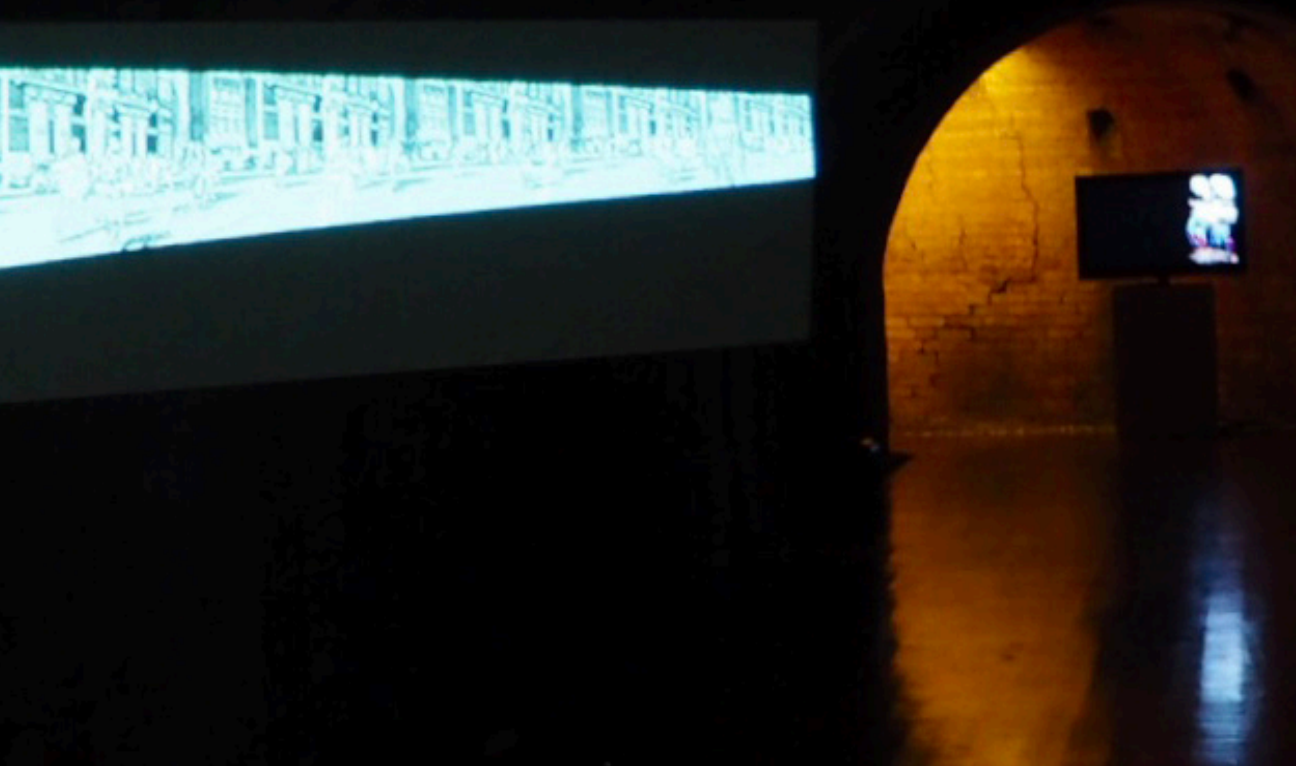

social e cultural. lugar é por isso metamórfico, sendo o tempo, o seu principal escultor e alquimista, recordando aqui a perseverança de António López García, ao realizar durante anos pinturas de lugares como a Gran Via, pelas 6h30, procurando registar o que parecia permanecer estático, mas que estava, obviamente, em mudança.

O lugar é então, espaço e tempo! O espaço tem a garantia de permanência durante um micro-instante, como sucedâneo de eventos contínuos que alteram e metamorfoseiam a sua dimensão estrutural. Essas alterações são apenas identificáveis por comparação, quando, num segundo momento, o relacionamos com um momento anterior. O tempo, por sua vez, é visível quando contabilizado, ou, também por comparação entre um antes e um depois.

Assim, o lugar já não é um espaço. O lugar é uma combinação de espaço e tempo em permanente mudança, em contínua transfiguração, que origina consecutivamente a redefinição da noção desse território. Assim, o lugar é matéria de camadas, como um relógio onde cada instante acrescenta nova identidade e que varia a cada novo olhar. Veja-se o exemplo da definição de lugar que a maioria dos habitantes e utilizadores de Nova Iorque têm até às 8 h45 do dia 11 de setembro de 2001. Essa definição altera-se dramaticamente ao longo da sucessão de eventos ocorridos nas horas seguintes. Veja-se ainda 
que ocurren en las horas siguientes. Vea también lo que cada uno de nosotros piensa sobre el espacio al que asiste diariamente en los períodos antes y después de una pandemia.

Cada capa de tiempo reconstruye una cierta noción de lugar, en una amalgama de experiencias, recuerdos, sensaciones y conceptos. Los lugares son cuerpos de tiempo, donde los eventos se superponen como estratos geofísicos, superponiéndose, borrando o camuflando las capas anteriores. Obsérvese el espacio del Forum de Ermesinde, donde tiene lugar esta exposición: un horno de cerámica inactivo, ejemplo de la importancia industrial de la zona hasta mediados del siglo XX, ahora envuelto en una cápsula de metal y madera, al servicio de la cultura y la estética. La pregunta sigue siendo: - ¿Qué función de este lugar será más importante: la industrial o la artística?, retórica que origina la reflexión de saber que la industria allí tenía un importante foco de actividad a través de la actual función de promoción del arte. De esta manera, cada capa impone un significado a la anterior y a la posterior, asumiendo y consolidándose en la voluntad de proteger la memoria cultural de un lugar con diferentes funciones, pero también de su comunidad.

Como se puede ver en la formación de este lugar, Luz Bañón lo hace en un intento de afirmar su propia noción de espacio y lugar, pero buscando preservar las funciones y memorias dentro de los territorios que sirven a su investigación. Murcia, Oporto, o cualquier otra geografía, forman parte de un inmenso cuerpo estratificado, donde el tiempo y el espacio son digeridos en la metamorfosis de sus relojes, los interlocutores que interactúan con el espacio - nosotros. Luz busca, en una acción entre el arqueólogo y el documentalista, recuperar parte de esta relación entre comunidad y territorio, buscando activar la dimensión histórica de su construcción, pero sobre todo, la identificación de una dimensión simbiótica de la construcción de memorias entre el espacio y la sociedad.

Así, como espectadores de esta exposición, se nos da la oportunidad de reconstruir el lugar y las marcas del paso del tiempo que la autora selecciona, asociándolas a nuestras propias nociones sobre esos espacios, pero también de repensar todo el territorio que nos rodea.

Zigmut Bauman, en su definición de Modernidad Líquida, a la que hace referencia el título de la exposición, o en las propuestas de Al-

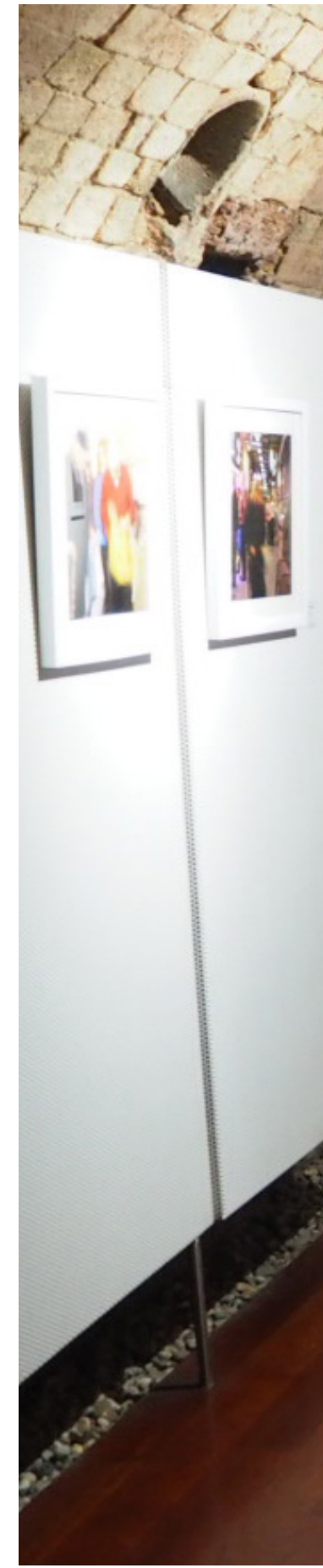




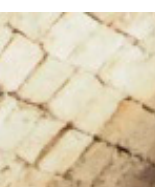




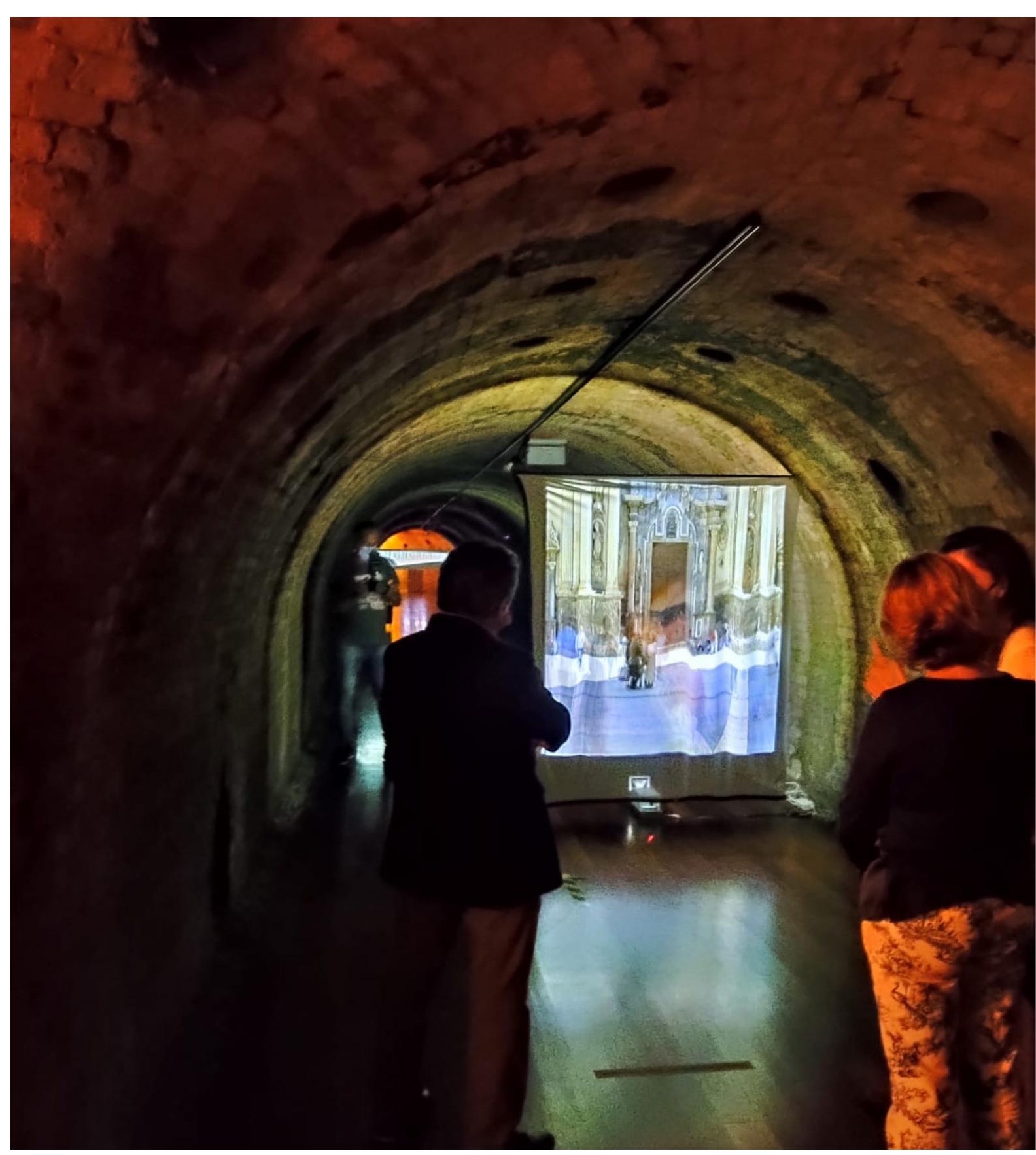


o que cada um de nós pensa sobre o espaço que frequenta diariamente nos periodos pré e pós pandemia.

Cada camada de tempo reconstrói uma determinada noção de lugar, numa amálgama de experiências, memórias, sensações e conceitos. Os lugares são corpos de tempo, onde os eventos se sobrepõem como estratos geofísicos, sobrepondo-se, apagando ou camuflando as camadas anteriores. Repare-se no espaço do Forum de Ermesinde, onde decorre esta exposição: um forno de cerâmica desativado, exemplo da importância industrial da zona até meados do século XX, agora, envolto numa cápsula de metal e madeira, servindo a cultura e a estética. Fica a questão: - Que função deste lugar será mais importante: a industrial ou a arte?, retórica que origina a reflexão de sabermos que a industria ali teve um importante foco de actividade através da actual função de promover a arte. Desta forma, cada camada impõe sentido à camada anterior e posterior, assumindo e consolidando-se na vontade de proteger a memória cultural de um lugar com diferentes funções, mas também da sua comunidade.

À imagem do que se pode verificar na formação deste lugar, o faz Luz Bañón, numa busca pela afirmação da sua própria noção de espaço e de lugar, mas procurando preservar as funções e as memórias intra camadas existentes nos territórios que servem a sua investigação. Múrcia, Porto, ou qualquer outra geografia, são parte de um imenso corpo estratificado, onde tempo e espaço se digladiam na metamorfose dos seus relógios, os interlocutores que interagem com o espaço - nós. Luz procura, numa ação entre o arqueológico e o arquivista, recuperar parte dessa relação entre comunidade e território, procurando ativar a dimensão histórica da construção dos mesmos, mas sobretudo, da identificação de uma dimensão simbiótica da construção de memórias entre espaço e sociedade.

Assim, enquanto espectadores desta exposição, é-nos dado a reconstruir o lugar e as marcas da passagem do tempo que a autora seleciona, associando-as com as nossas próprias noções relativas àqueles espaços, mas também a repensar todo o território que nos envolve.

Zigmut Bauman, na sua definição de Modernidade Líquida, a que o título da exposição recorre, ou nas propostas de Altermodernida- 
termodernidad, de Nicolas Bourriaud, son dos de las definiciones del tiempo actual que pueden guiarnos en la comprensión de la conjugación y constante mutación de los interlocutores - sociedad, sujeto y espacio - pero que también nos permiten justificar lo que Immanuel Kant ya denominó espacio y tiempo son dos agentes trascendentales, indefinibles, a los que no podemos ser inmunes, y que en continuo, dejan marcas en nuestro cuerpo.

Así, esta exposición es, además de un territorio de estímulo y experimentación estética e intelectual, un relato de la transfiguración operada por el tiempo sobre el espacio en una notable simbiosis con el Foro de Ermesinde, un retrato visible de la impermanencia y la constante mutación del lugar.

Luz, nos permite acceder y experimentar un camino construido por la conjugación de la investigación con la sensibilidad, respetando los espacios y las capas que la complementan, valorando a las personas, los individuos y la cultura local, en una manifestación continua del valor de la preservación de la memoria y la constante interconexión entre todo. De esta manera, tal vez, no se pueda garantizar que el sentido del lugar se clarifique, pero ciertamente nuestra atención se activará más para la valorización de todos los signos de la presencia del tiempo, para la mutación del lugar y para la importancia que cada uno tiene en la construcción de nuevas definiciones y nuevas imágenes del territorio.

Aprovecho la ocasión para agradecer al Ayuntamiento de Valongo la posibilidad de unir estos dos territorios, el de la artista y el del espacio del Foro de Ermesinde, en un diálogo que complementa la narración de cada espacio-tiempo, de cada lugar.

Gracias, Luz Bañón, por mirar atentamente el territorio, agudizando mi curiosidad, no sólo por cada una de sus obras, sino por todas y cada una de las cosas que frecuentan los espacios en los que me muevo, así como por las pistas de los estratos de la memoria que me permiten desvelar y respetar lo que el tiempo y el espacio han ido conformando en su trascendencia.

\section{Domingos Loureiro}

Investigador de i2ADS

Profesor FBAUP 
de, de Nicolas Bourriaud, são duas das definições do tempo actual e que nos podem orientar na compreensão da conjugação e mutação constante dos interlocutores - sociedade, sujeito e espaço - mas também nos permitem justificar o que já Immanuel Kant referia de que o espaço e o tempo são dois agentes transcendentais, indefiníveis, aos quais não conseguimos estar imunes, e que em contínuo, nos vão deixando marcas no corpo.

Assim, esta exposição é, além de um território de estímulo e experimentação estética e intelectual, um relato da transfiguração operada pelo tempo sobre o espaço numa notável simbiose com o Forum de Ermesinde, retrato visível da impermanência e constante mutação do lugar.

Luz, permite-nos aceder e experienciar um percurso construido pela conjugação da investigação com a sensibilidade, no respeito pelos espaços e pelas camadas que o complementam, valorizando gentes, indivíduos e cultura local, numa contínua manifestação do valor da preservação da memória e da interligação constante entre tudo. Desta forma, talvez, não se possa garantir que o sentido do lugar ficará esclarecido, mas certamente que a nossa atenção ficará mais activada para a valorização de todos os indícios da presença do tempo, para a mutação do lugar e para a importância que cada um tem na construção de novas definições e novas imagens do território.

Aproveito para saludar a Câmara Municipal de Valongo, pela possibilidade da conjugação destes dois territórios, o da artista e o do espaço do Forum de Ermesinde, num diálogo que complementa a narrativa de cada espaço-tempo, de cada lugar.

Obrigado, Luz Bañón, pelo olhar atento sobre o território, aguçando a minha curiosidade, não apenas para cada uma das tuas obras, mas para cada coisa e cada sujeito que frequenta os espaços onde me movimento, bem como para as pistas dos estratos de memórias que me permitam desvendar e respeitar o que o tempo e o espaço foram moldando na sua transcendência.

\section{Domingos Loureiro}

Inestigador $i 2 A D S$

Professor FBAUP 


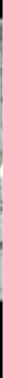




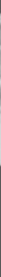

\section{DISCONTINUOU ECHO (2020)}

Instalación audiovisual (10 pantallas)

Duración 6:25 min (reproducción en bucle)

H.246 1080p 60Hz

Instalação audiovisual (10 ecrãs)

Duração 6:25 min (reprodução contínua)

H.246 1080p 60Hz 


\section{SERIE}

STEREOSCOPIC INTERVENTIONS-PORTO (2020)

Instalación audiovisual (3 pantallas)

H.246 1080p 60Hz

Instalação audiovisual (3 ecrãs)

H.246 1080p 60Hz
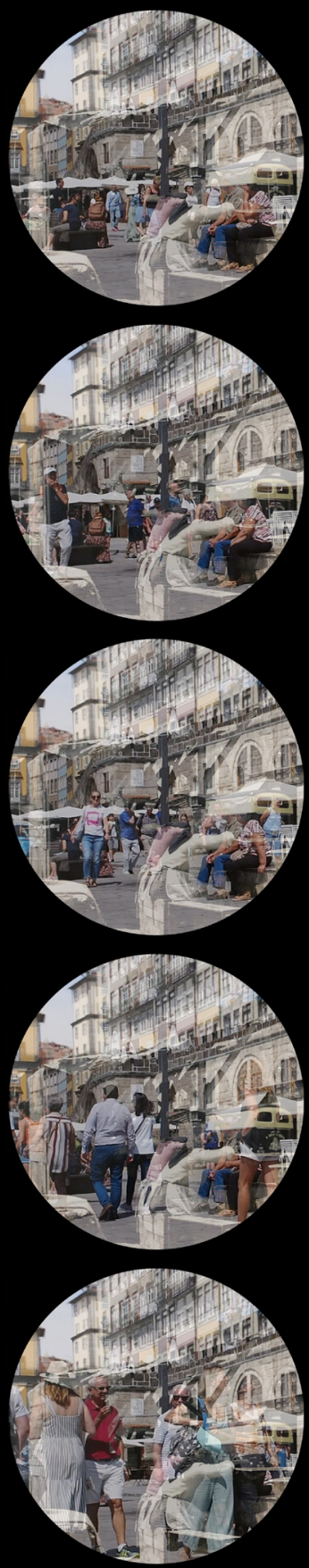

Stereoscopic Interventions Porto I-Ribeira

Duración 6:01 min (reproducción en bucle)

Duração 6:01 min (reprodução contínua) 

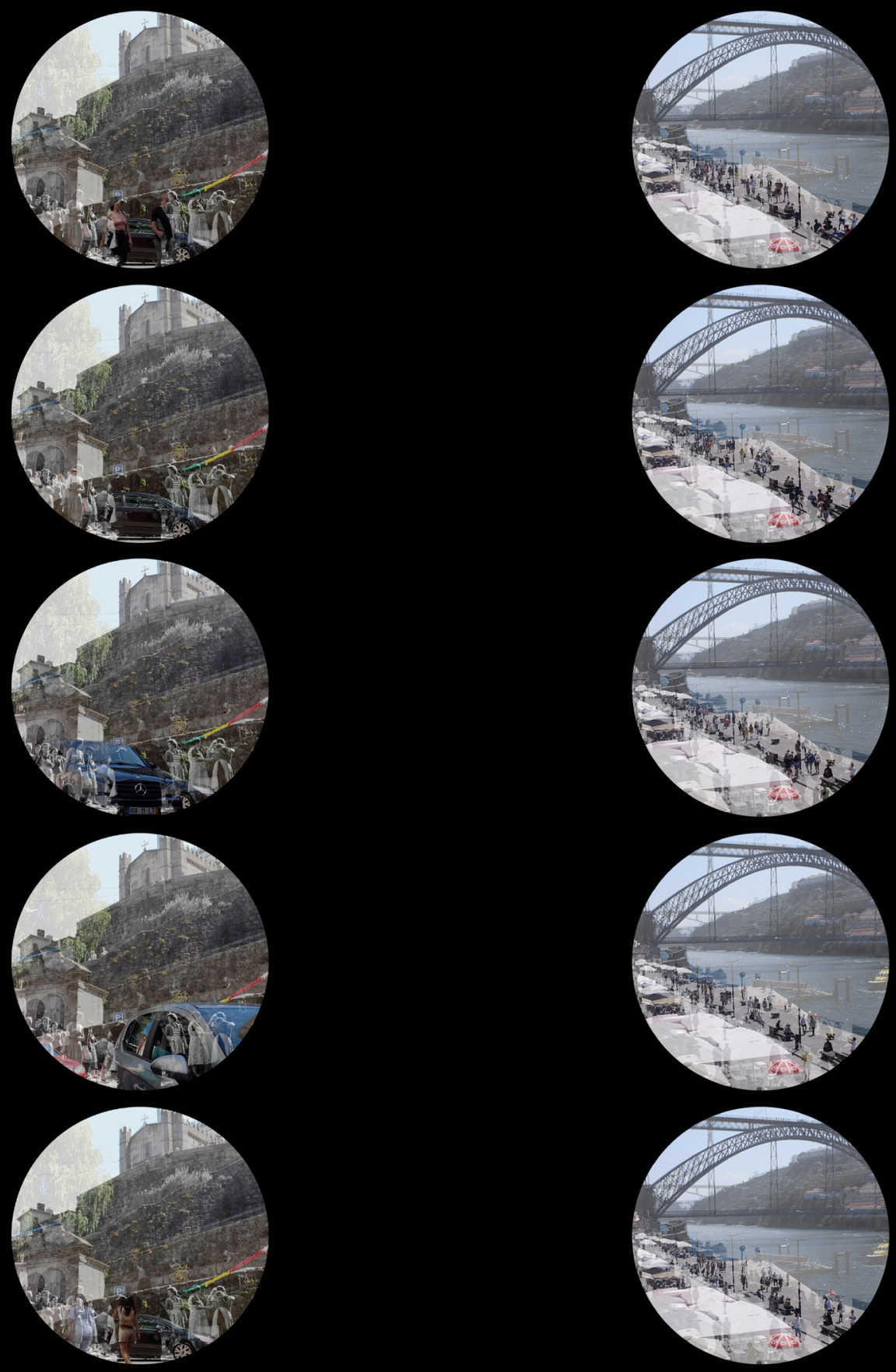

Stereoscopic Interventions Porto II-São Nicolau Duración 4:56 min (reproducción en bucle)

Duração 4:56 min (reprodução contínua)
Stereoscopic Interventions Porto III-Ponte Luiz I Duración 4:03 min (reproducción en bucle)

Duração 4:03 min (reprodução contínua) 
Time, Space and

Mutables Identities
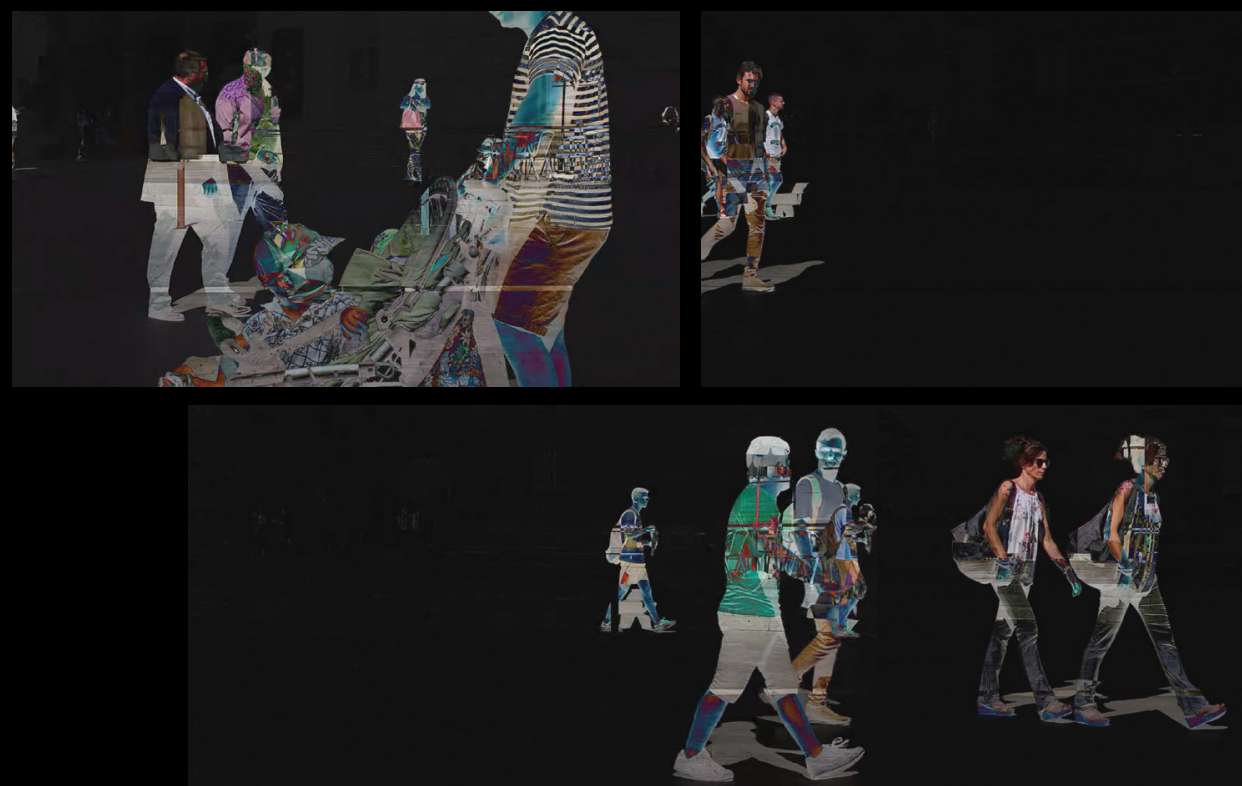

TIME SPACE AND MUTABLE IDENTITIES (2019)

Instalación audiovisual (monocanal)

Duración 8:46 min (reproducción en bucle)

H.246 1080p 60Hz

Instalação audiovisual (monocanal)

Duração 8:46 min (reprodução em laço)

H.246 1080p 60Hz 

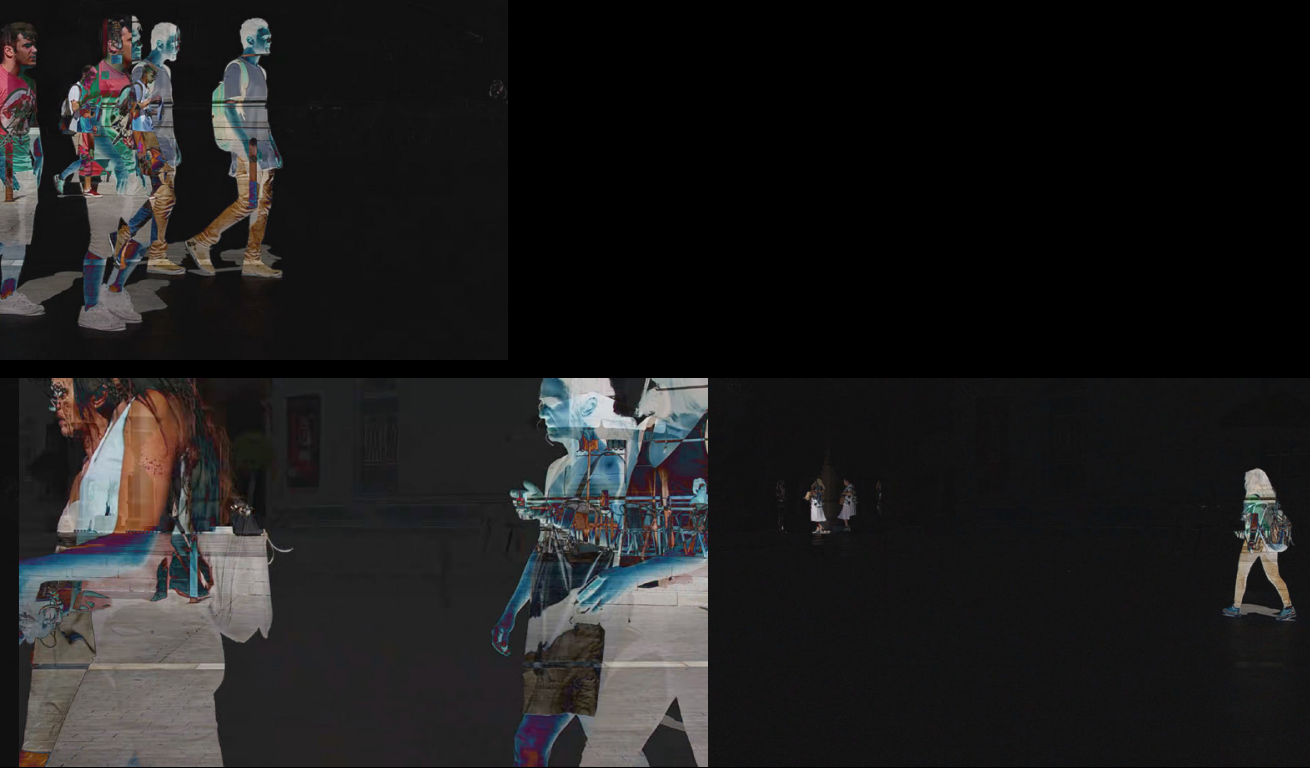

at

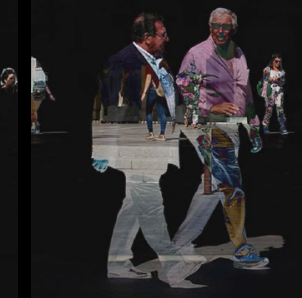



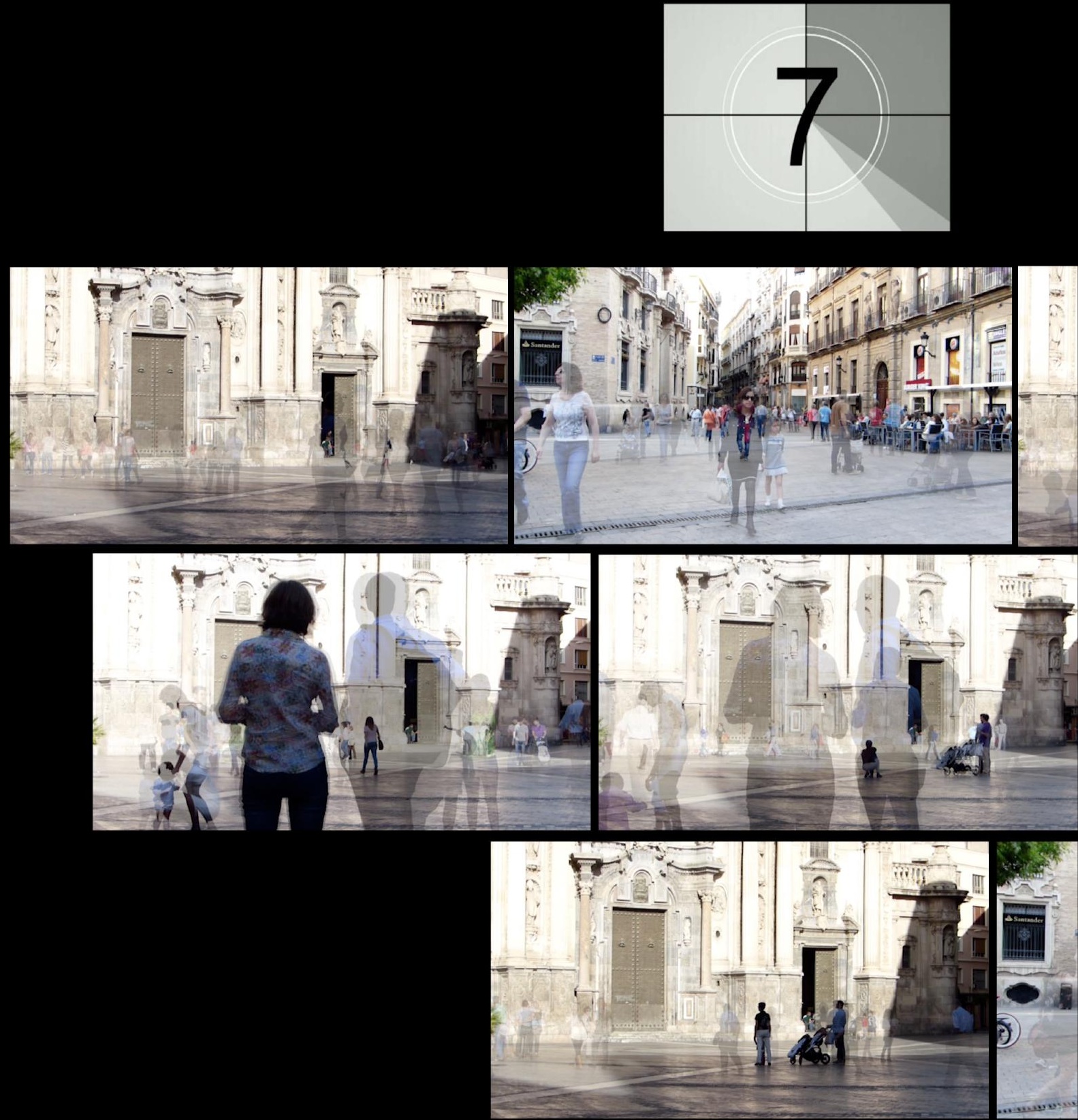

\section{SEVEN SECONDS (2018)}

Instalación audiovisual (monocanal)

Duración 15:00 min (reproducción en bucle)

H.246 1080p 60Hz

Instalação audiovisual (monocanal)

Duração 15:00 min (reprodução contínua)

H.246 1080p 60Hz 


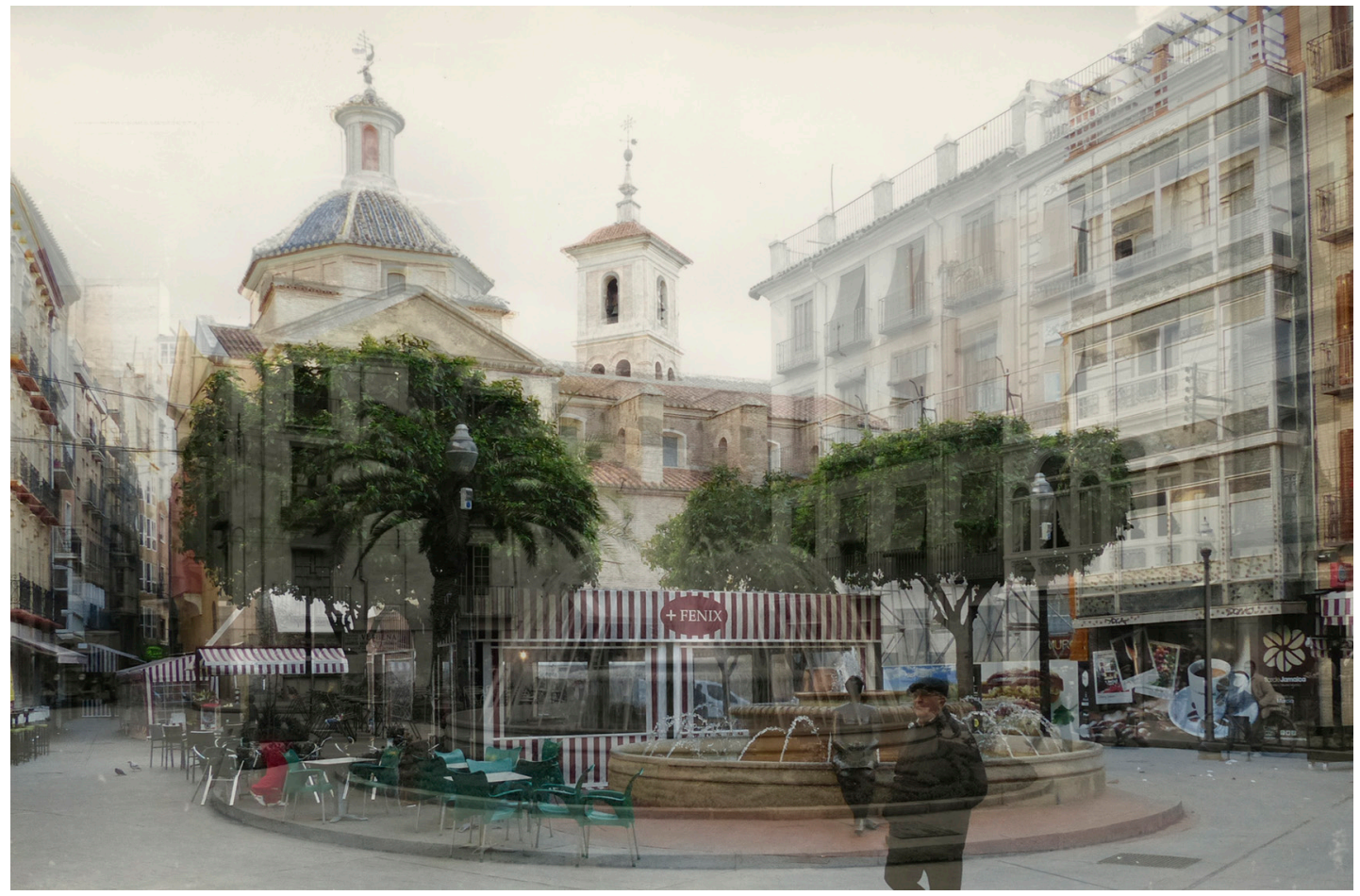

SERIE REFLEXIÓN TEMPORAL (2016-2018)

REFLEXIÓN TEMPORAL 1

Plaza de las flores (2016)

Fotografía

Impresión en HDPB system sobre PVC

$121 \times 80 \mathrm{~cm}$

Praça das flores (2016)

Fotografia

Impressão em sistema HDPB sobre PVC

$121 \times 80 \mathrm{~cm}$ 


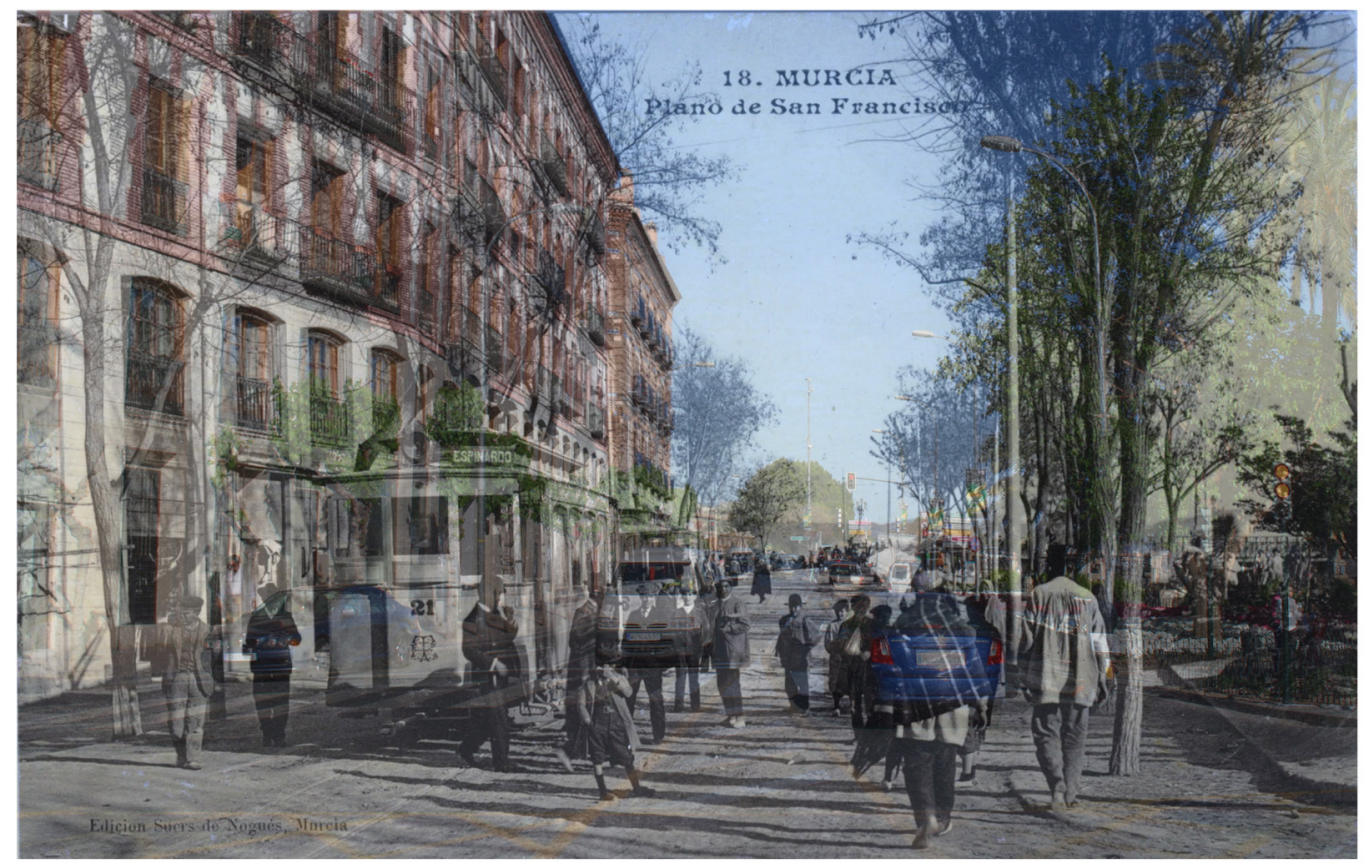

SERIE REFLEXIÓN TEMPORAL (2016-2018)

REFLEXIÓN TEMPORAL 2

Plano de San Francisco (2016)

Fotografía

Impresión en HDPB system sobre Cartón Pluma

$100 \times 65 \mathrm{~cm}$

Mapa de São Francisco (2016)

Fotografia

Impresso no sistema HDPB em K-Line

$100 \times 65 \mathrm{~cm}$ 


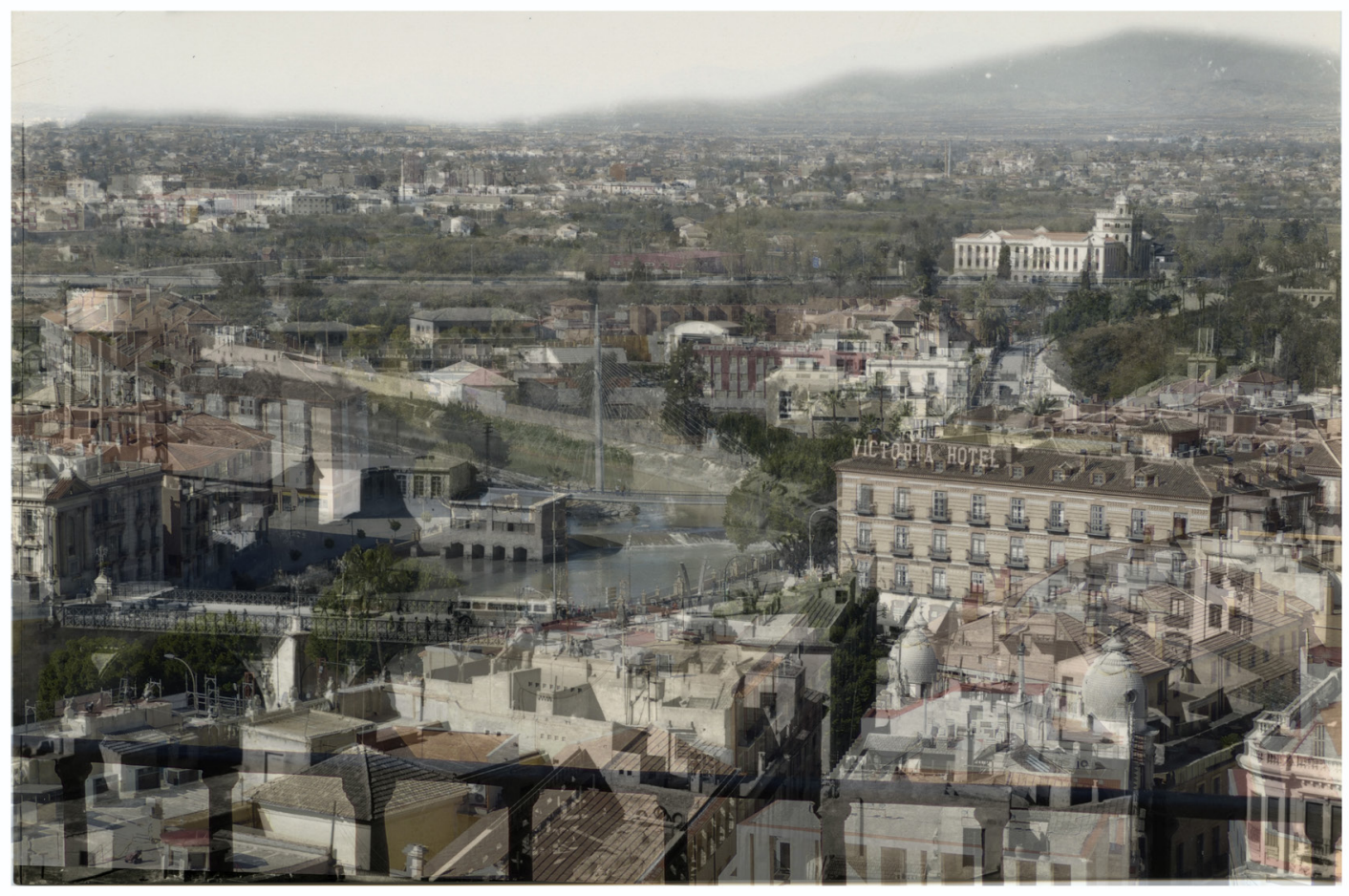

SERIE REFLEXIÓN TEMPORAL (2016-2018)

REFLEXIÓN TEMPORAL 3

Murcia desde la Catedral (2017)

Fotografía

Impresión retroiluminada

Backlight $102 \times 72 \mathrm{~cm}$

Múrcia da Catedral (2017)

Fotografia

Impressão retroiluminada

Backlight 102 × $72 \mathrm{~cm}$ 


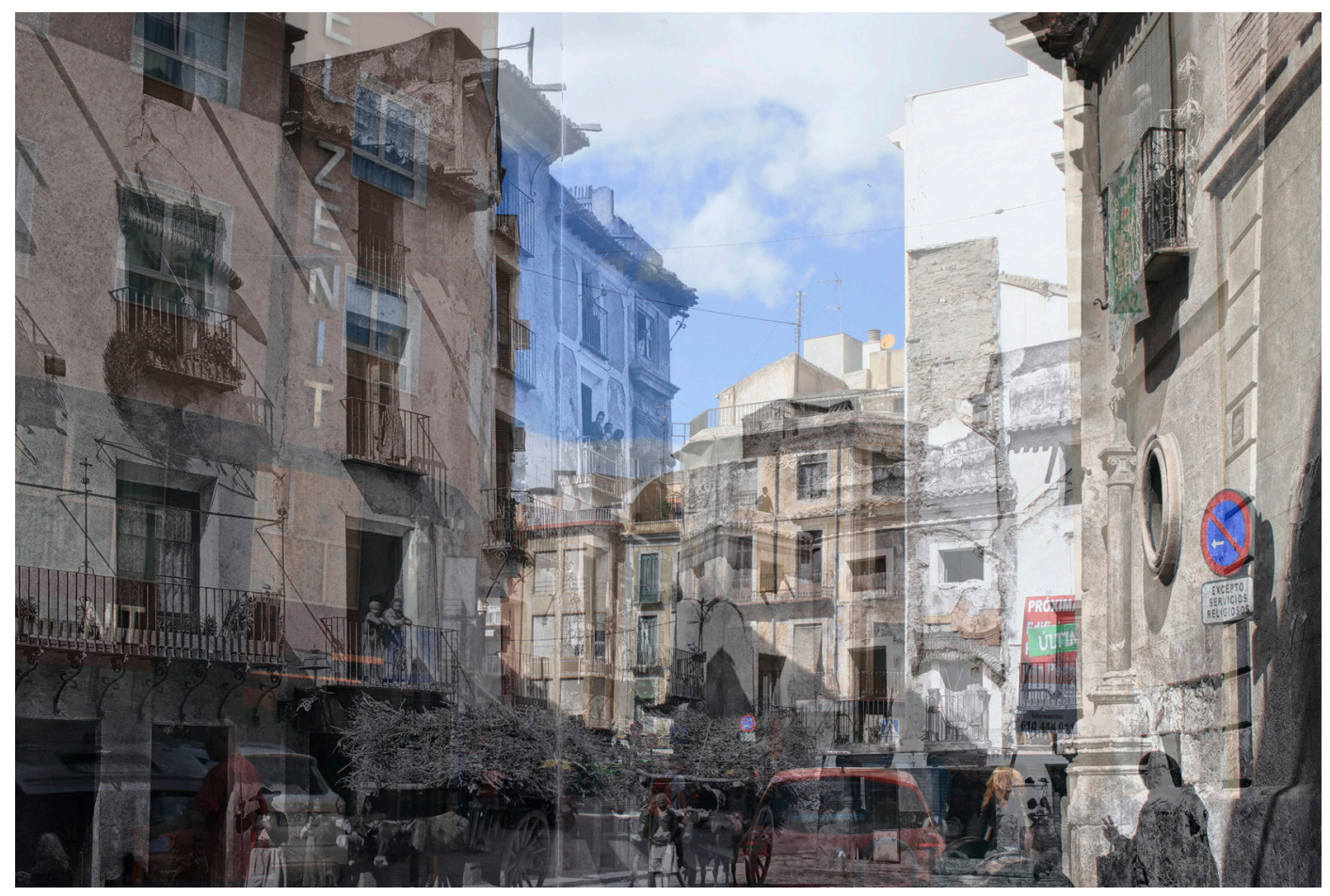

SERIE REFLEXIÓN TEMPORAL (2016-2018)

REFLEXIÓN TEMPORAL 4

Plaza de San Pedro (2017)

Fotografía

Impresión retroiluminada

Backlight $102 \times 72 \mathrm{~cm}$

Praça de São Pedro (2017)

Fotografia

Impressão retroiluminada

Backlight $102 \times 72 \mathrm{~cm}$ 


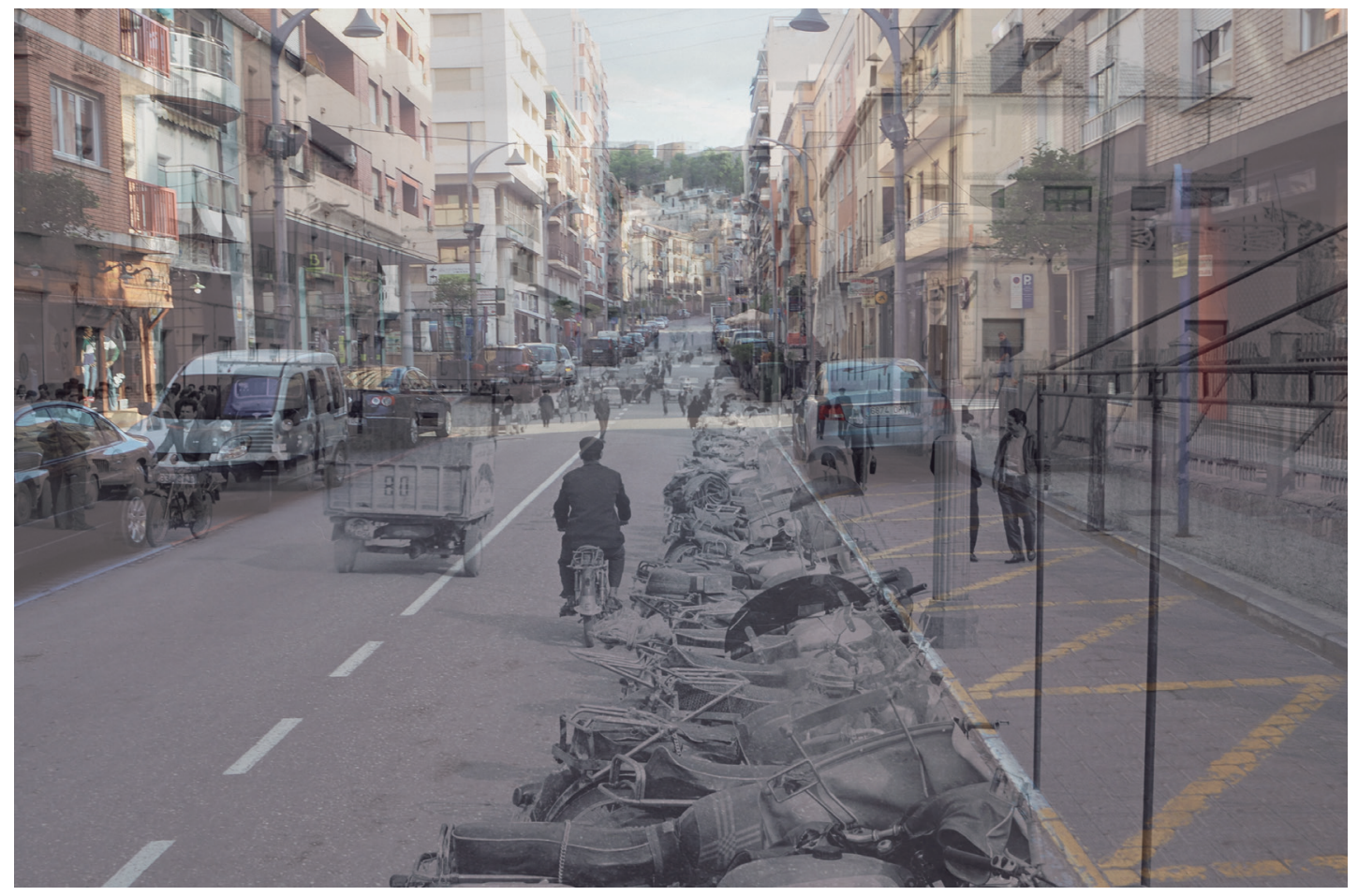

SERIE REFLEXIÓN TEMPORAL (2016-2018)

REFLEXIÓN TEMPORAL 6

Gran Vía Caravaca (2018)

Fotografía

Impresión Pegasus Light Force

$121 \times 80 \mathrm{~cm}$

Gran Vía Caravaca (2018)

Fotografia

Impressão Pegasus Light Force

121 x $80 \mathrm{~cm}$ 


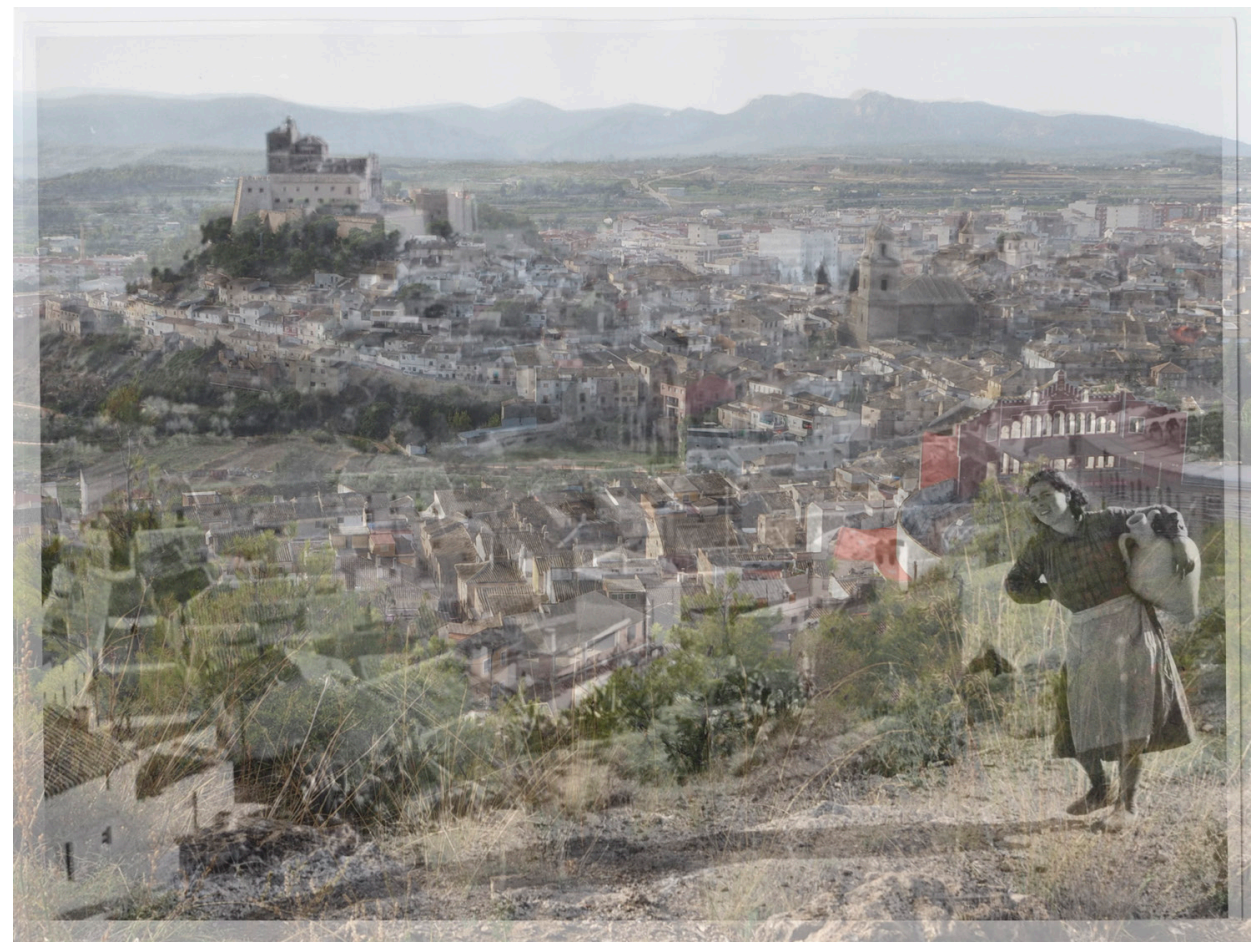

SERIE REFLEXIÓN TEMPORAL (2016-2018)

REFLEXIÓN TEMPORAL 7

Caravaca (2018)

Fotografía

Impresión Pegasus Light Force

$106 \times 80 \mathrm{~cm}$

Caravaca (2018)

Fotografia

Impressão Pegasus Light Force

$106 \times 80 \mathrm{~cm}$ 


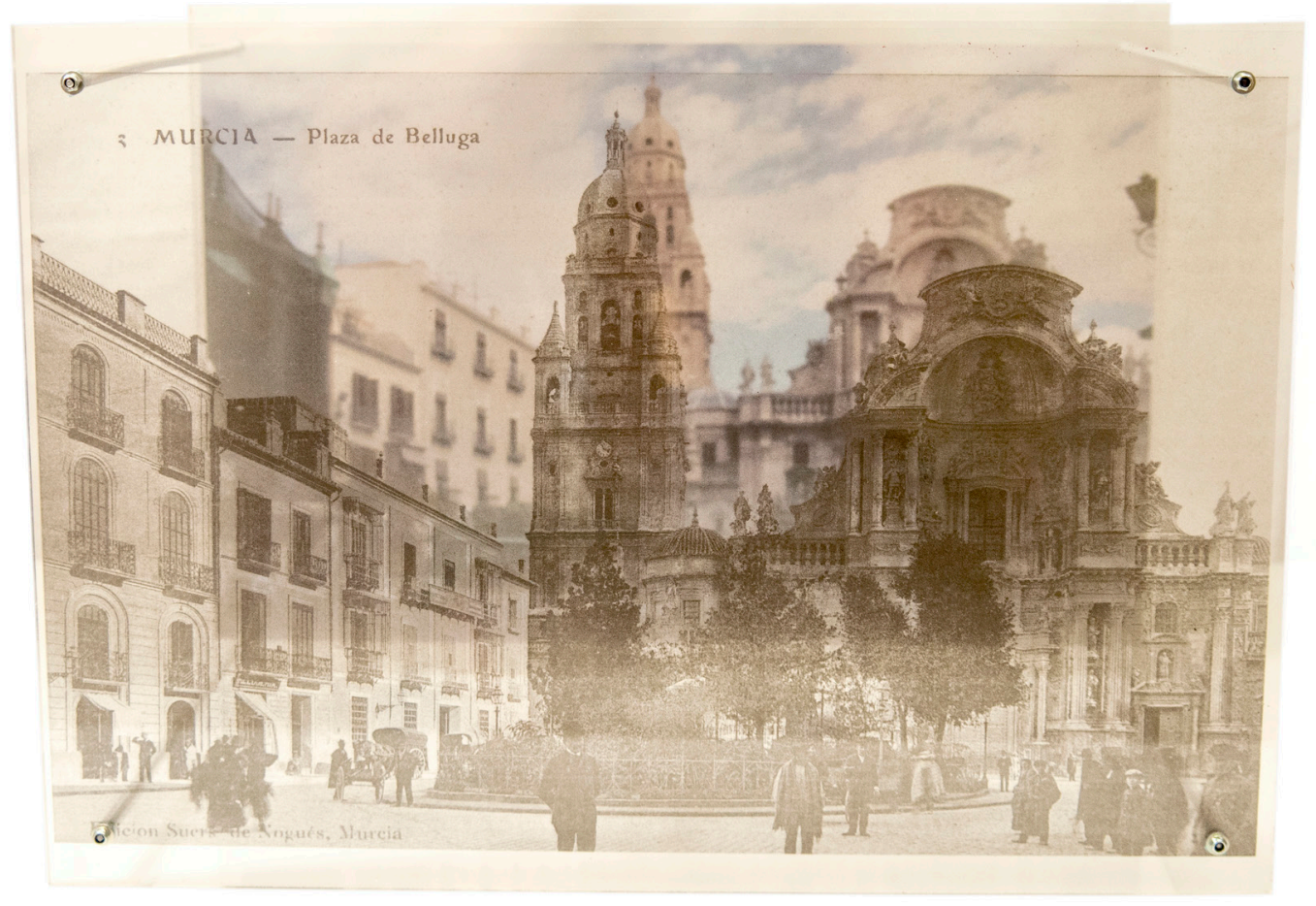




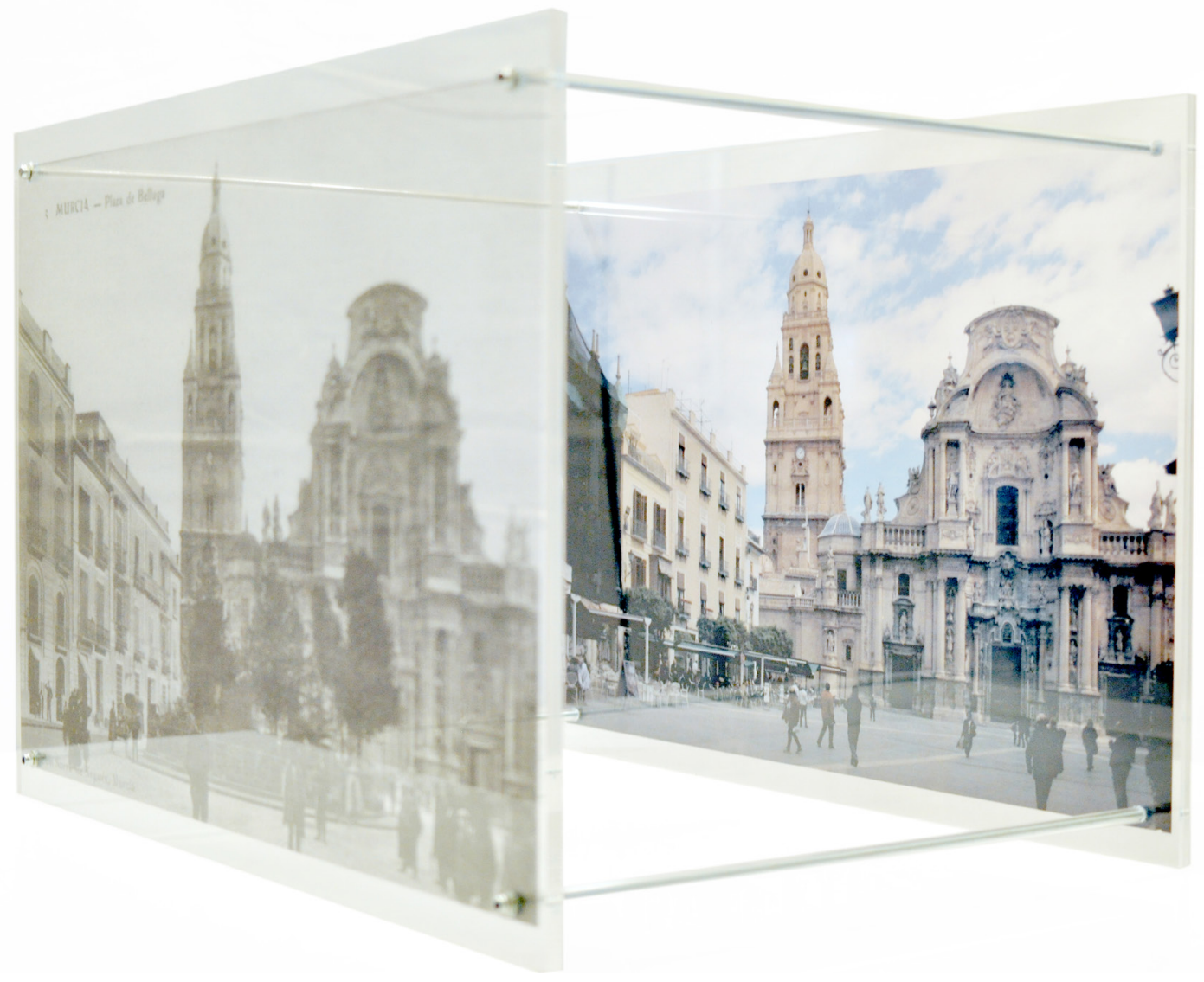

SERIE CAJA DE HISTORIAS 1

Plaza Belluga (2016)

Fotografía

Metacrilato y acetato

$42 \times 30 \times 30 \mathrm{~cm}$

Praça Belluga (2016)

Fotografia

Metacrilato e acetato

$42 \times 30 \times 30 \mathrm{~cm}$ 


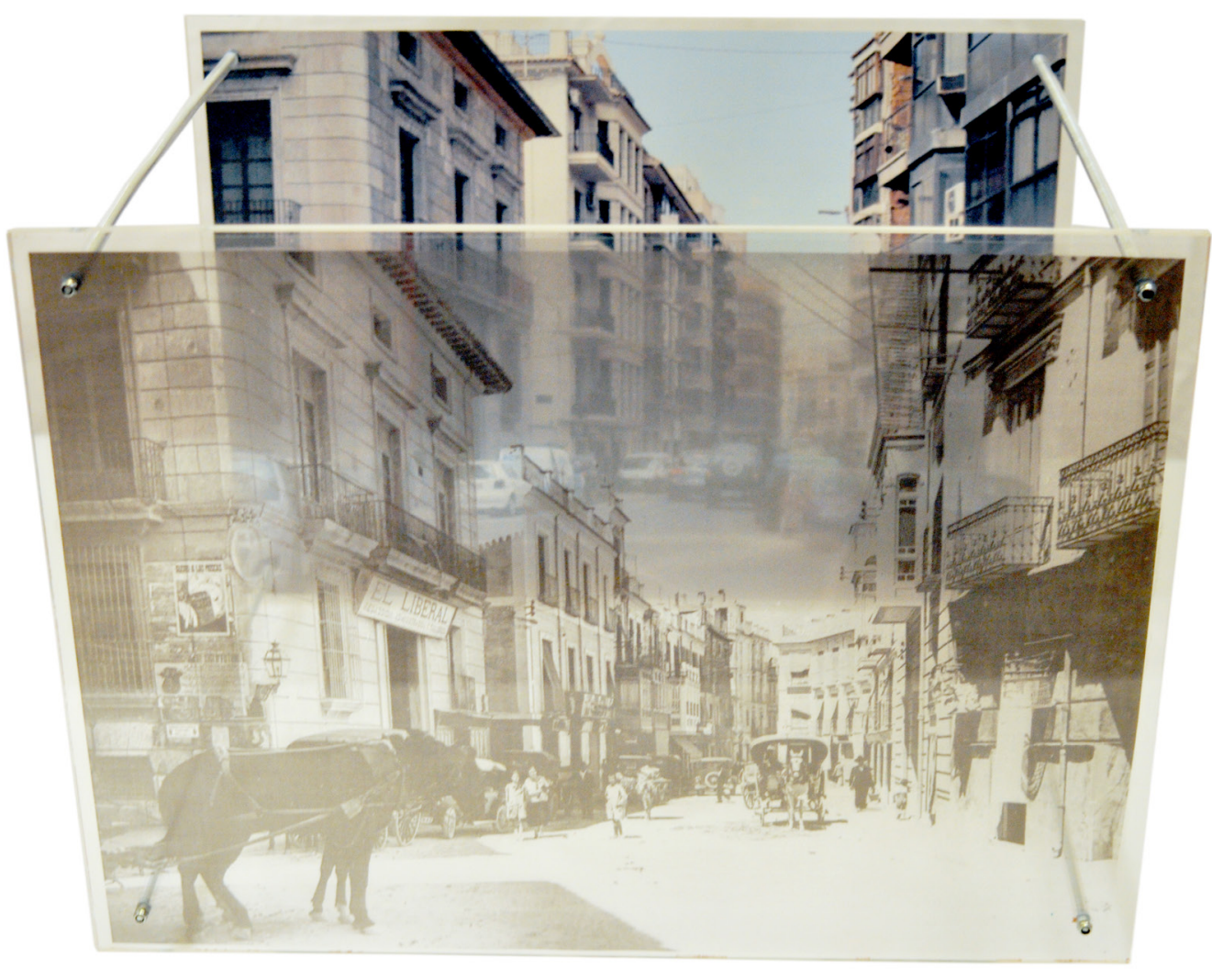




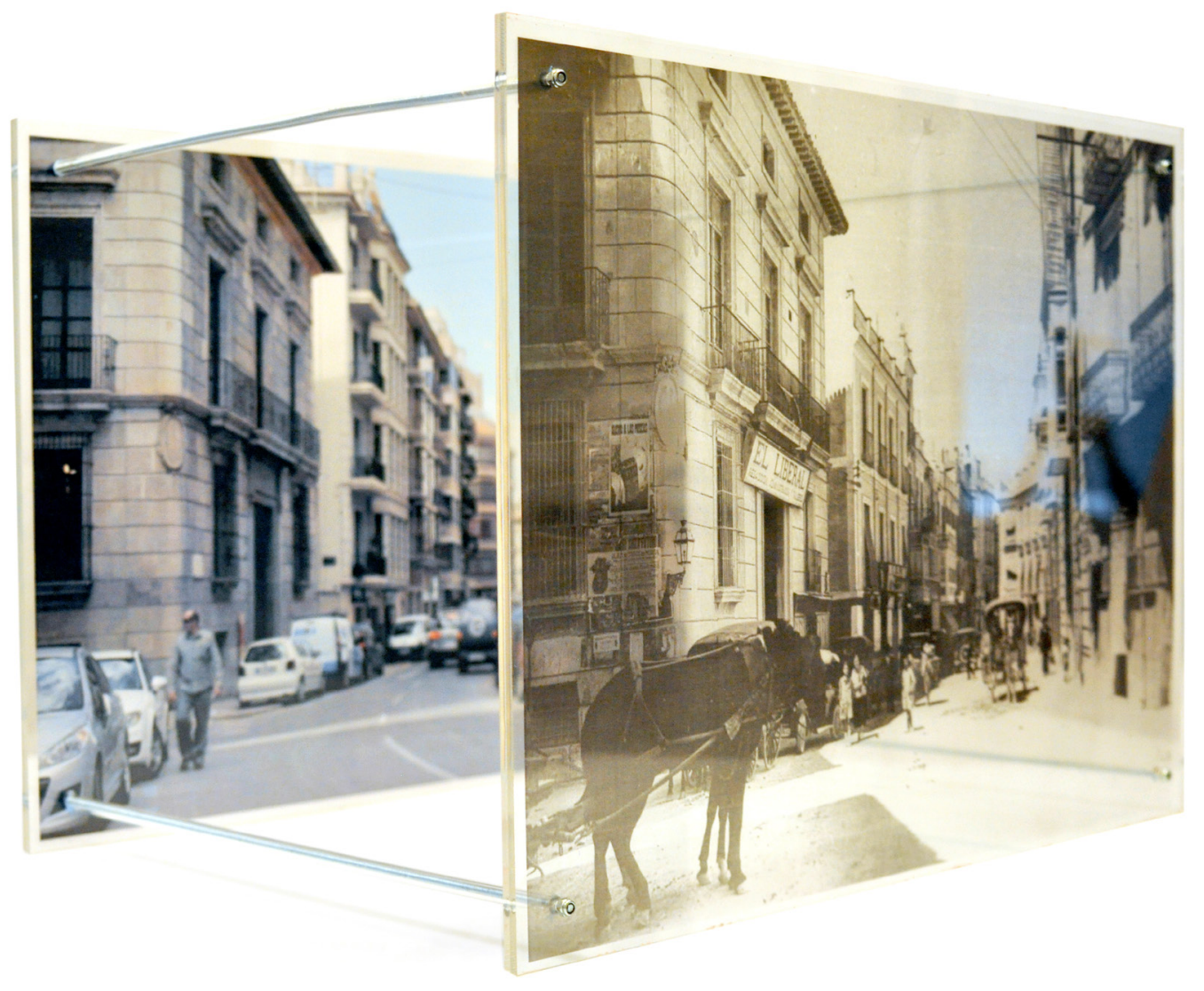

SERIE CAJA DE HISTORIAS 3

Jara Carrillo (2016)

Fotografía

Metacrilato y acetato

$42 \times 30 \times 30 \mathrm{~cm}$

Jara Carrillo (2016)

Fotografia

Metacrilato e acetato

$42 \times 30 \times 30 \mathrm{~cm}$ 


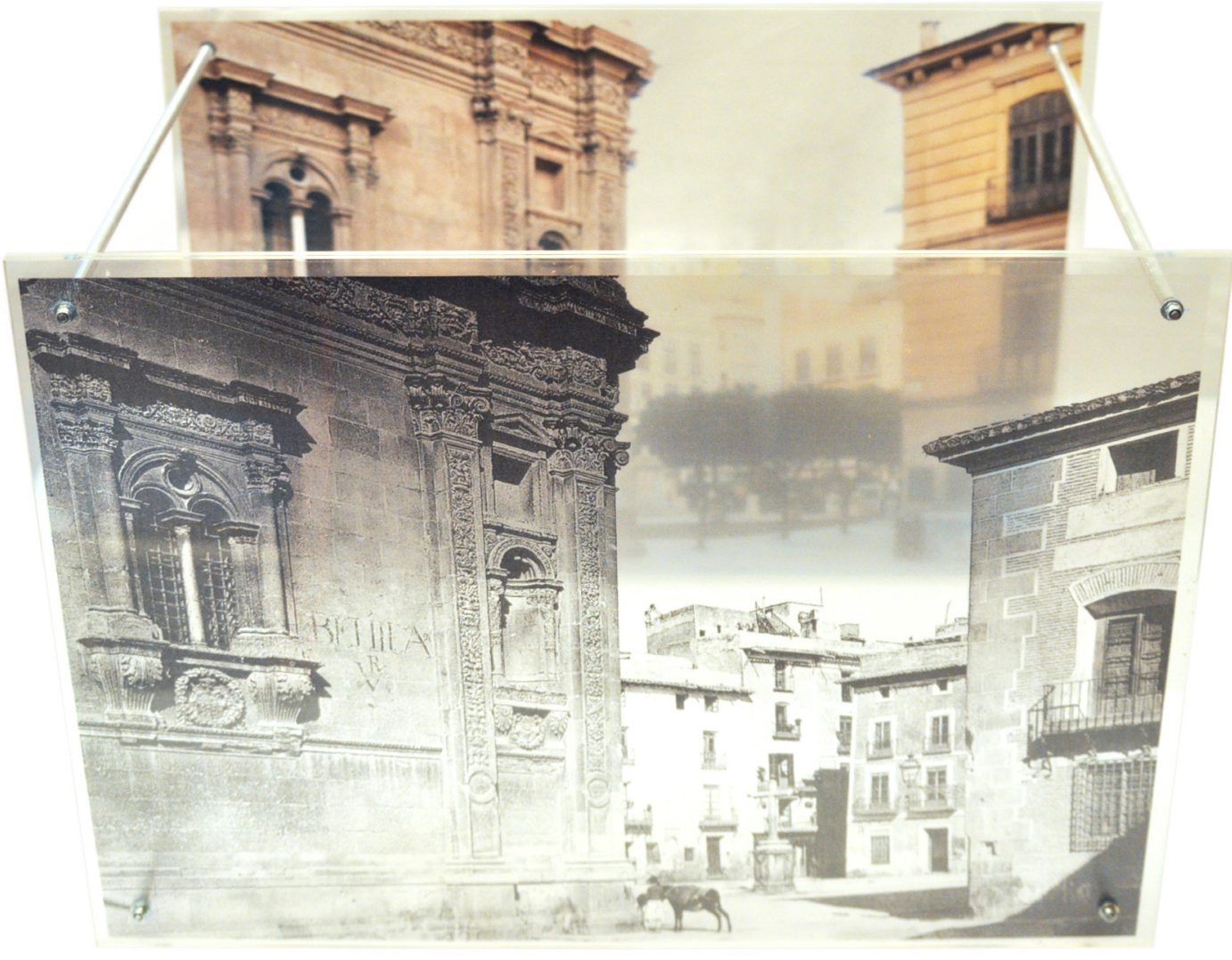




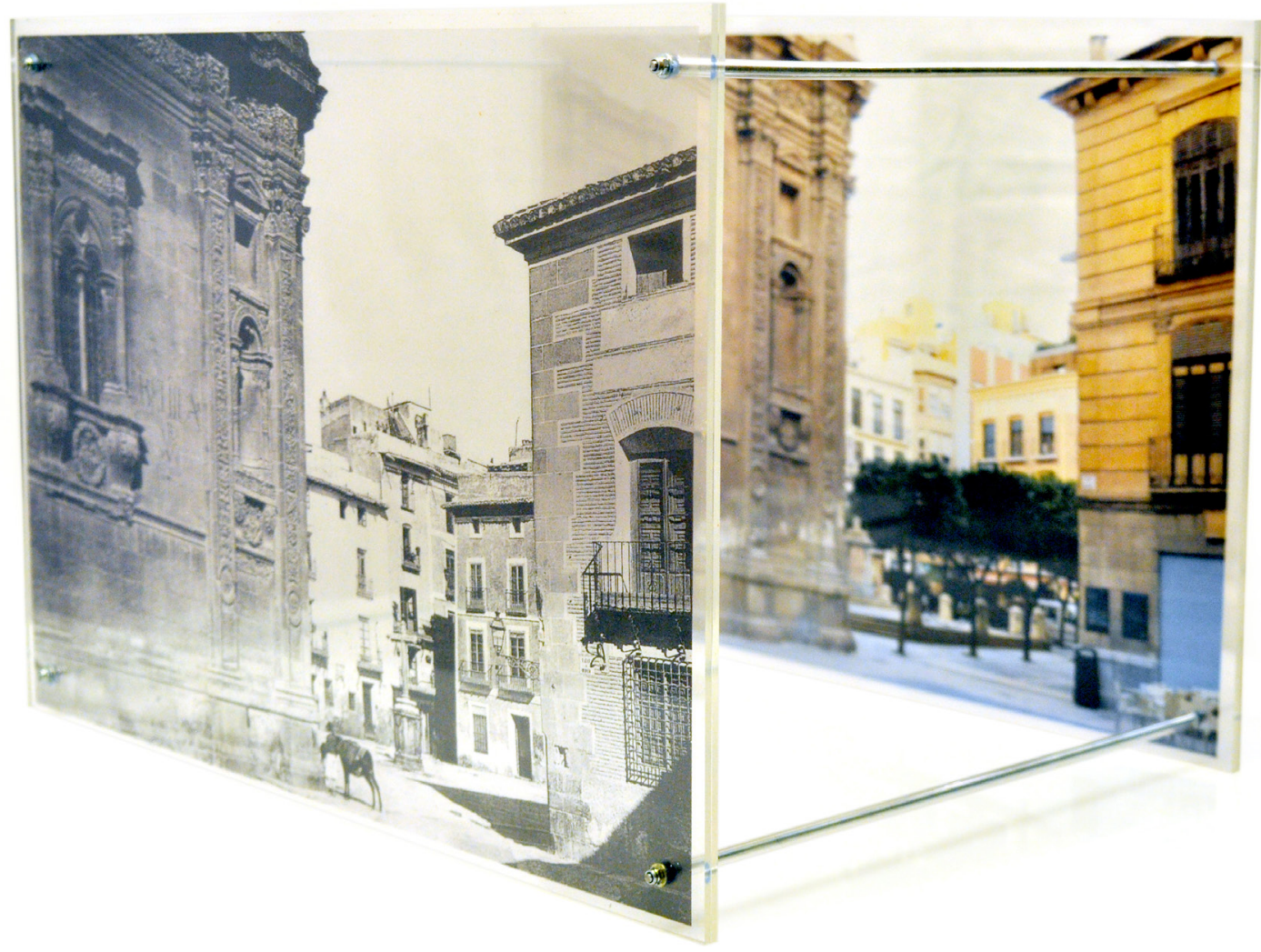

\section{SERIE CAJA DE HISTORIAS 4}

Plaza de la Cruz (2016)

Instalación fotográfica

Metacrilato y acetato

$42 \times 30 \times 30 \mathrm{~cm}$

Plaza de la Cruz (2016)

Instalação fotográfica

Metacrilato e acetato

$42 \times 30 \times 30 \mathrm{~cm}$ 


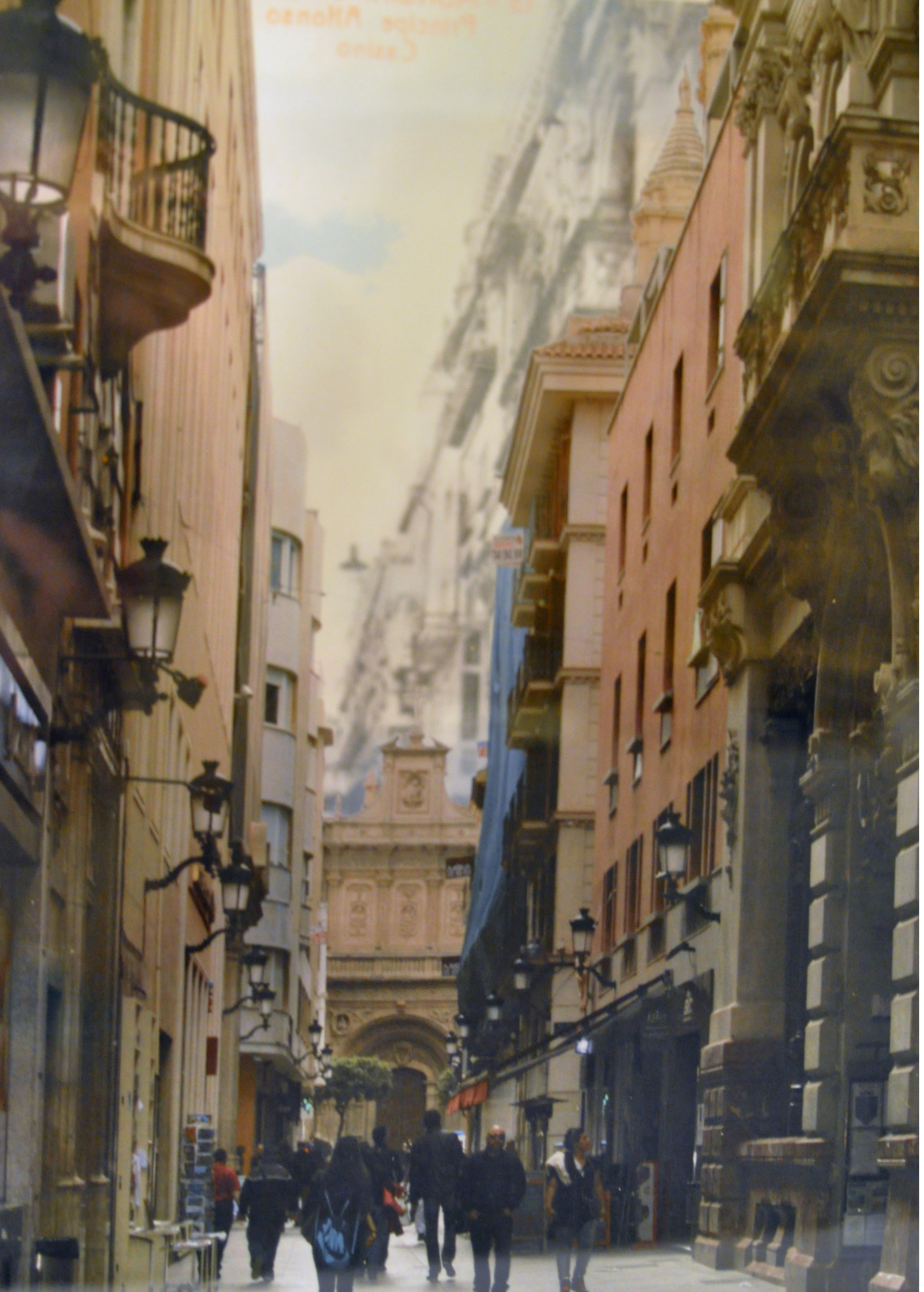




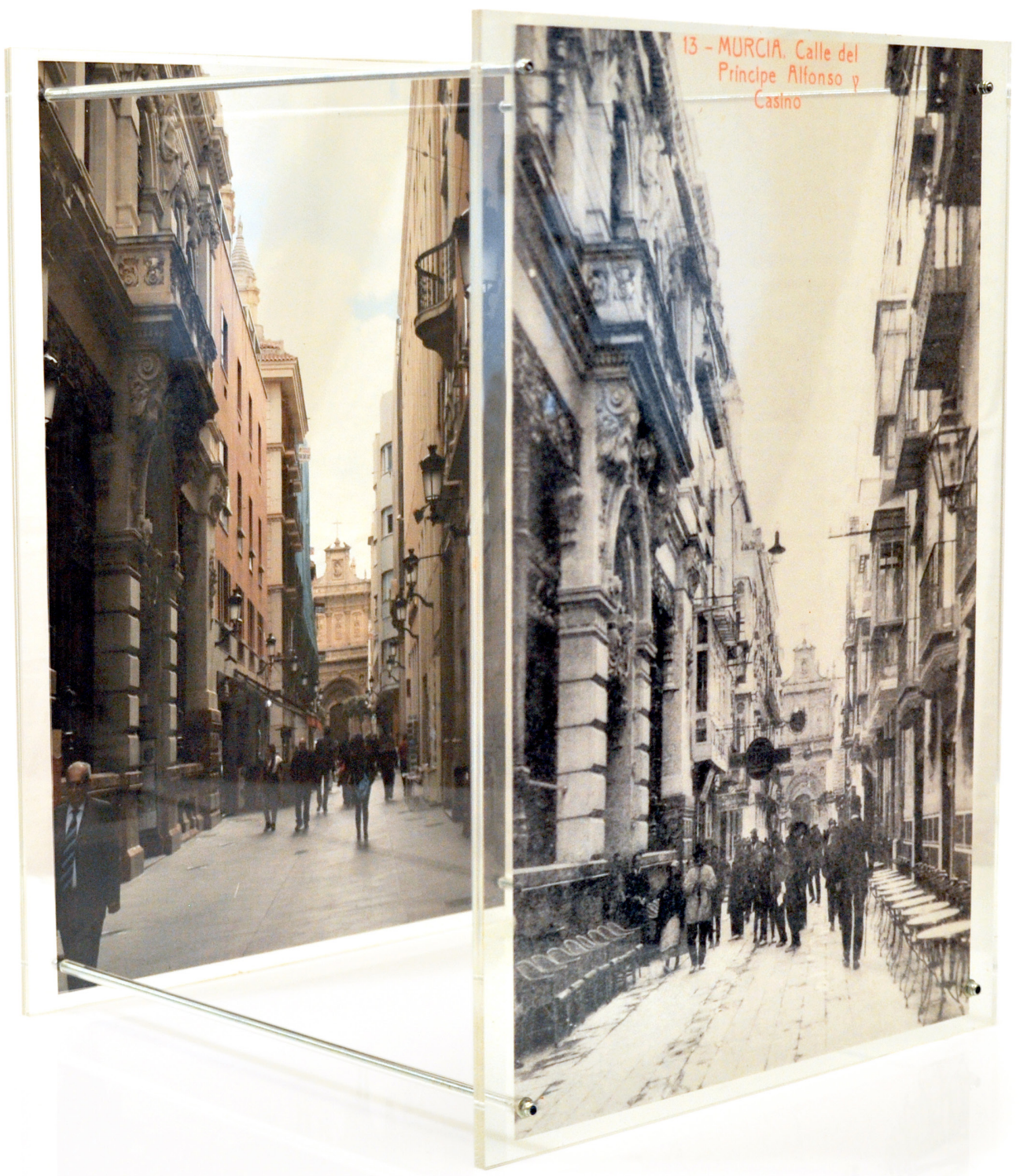

SERIE CAJA DE HISTORIAS 5

Casino (2016)

Fotografía

Metacrilato y acetato

$42 \times 30 \times 30 \mathrm{~cm}$

Casino (2016)

Fotografia

Metacrilato e acetato

$42 \times 30 \times 30 \mathrm{~cm}$ 


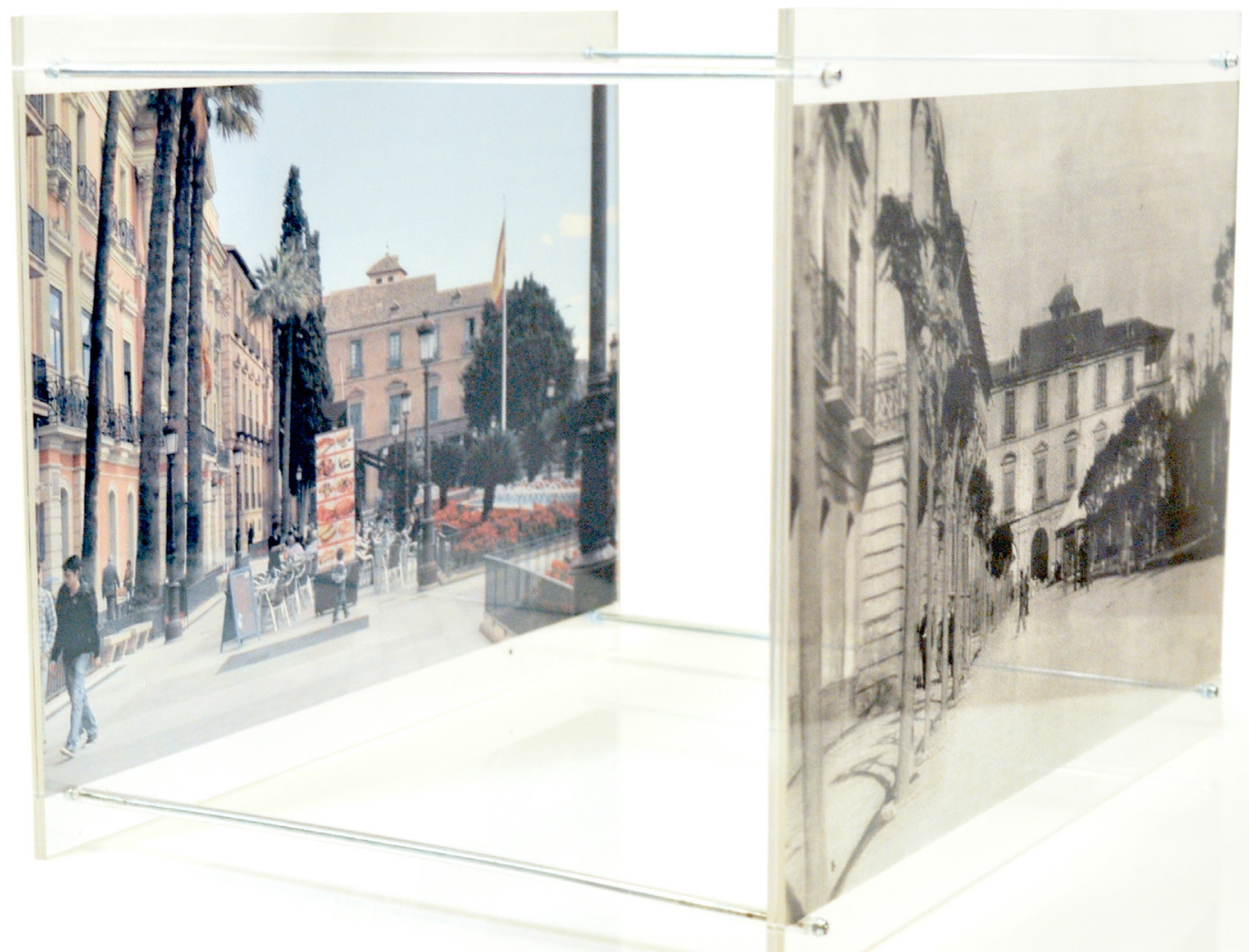




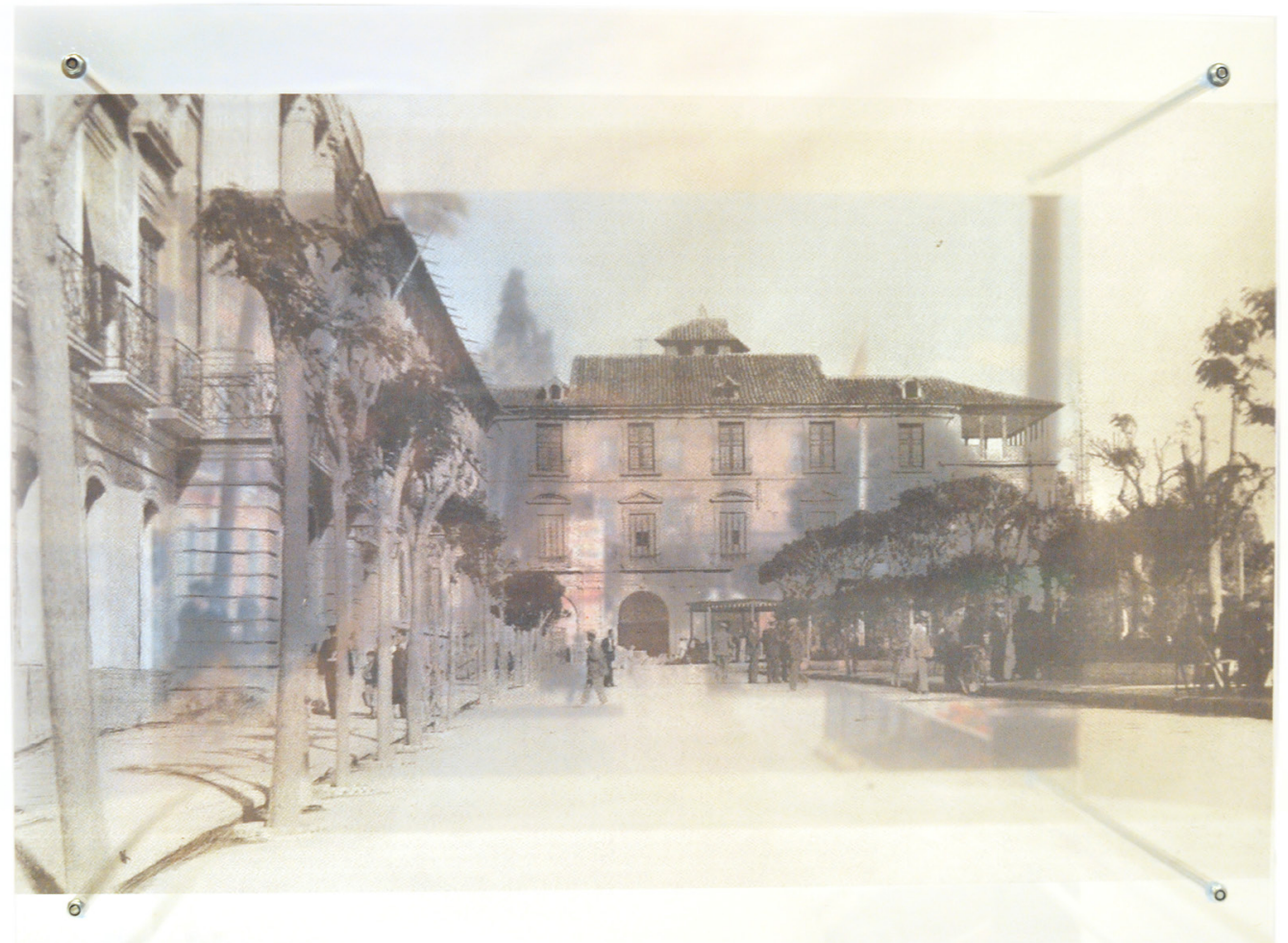

SERIE CAJA DE HISTORIAS 6

Glorieta de España

Fotografía

Metacrilato y acetato

$42 \times 30 \times 30 \mathrm{~cm}$

Rotunda espanhola

Fotografia

Metacrilato e acetato

$42 \times 30 \times 30 \mathrm{~cm}$ 


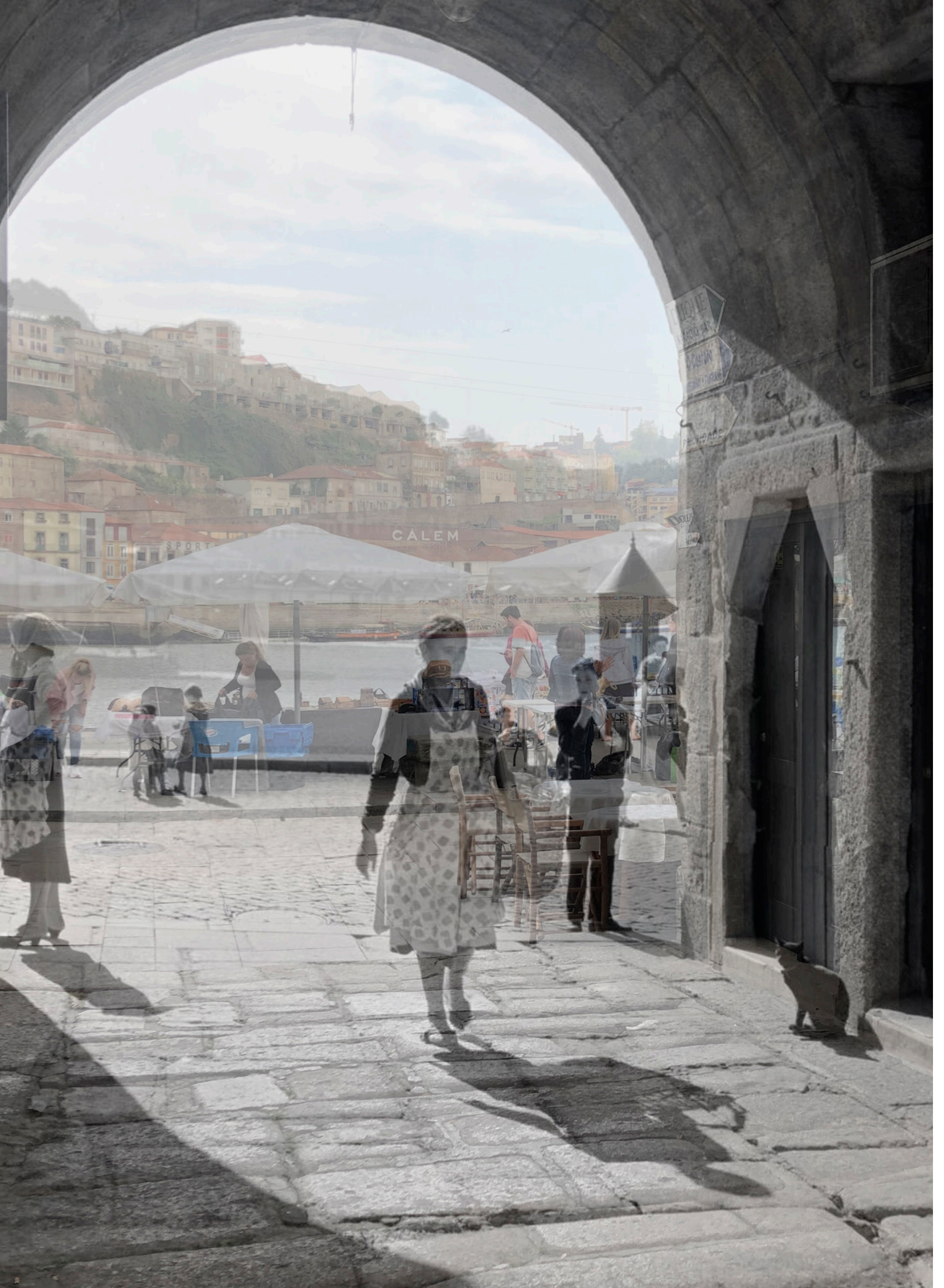




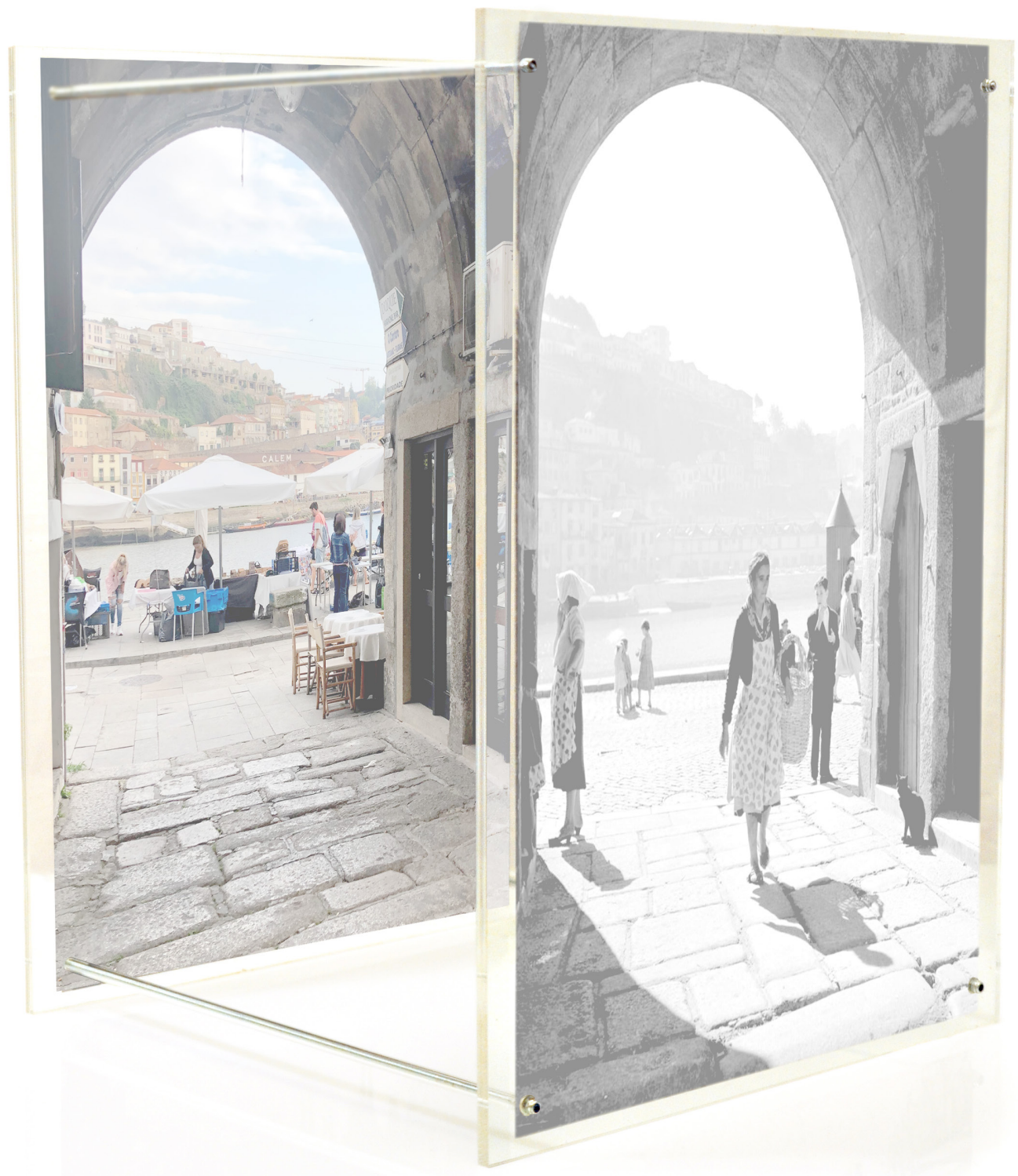

SERIE CAJA DE HISTORIAS 12

Arco na Ribeira Porto

Fotografía

Metacrilato y acetato

$42 \times 30 \times 30 \mathrm{~cm}$

Arco na Ribeira Porto

Fotografia

Metacrilato e acetato

$42 \times 30 \times 30 \mathrm{~cm}$ 


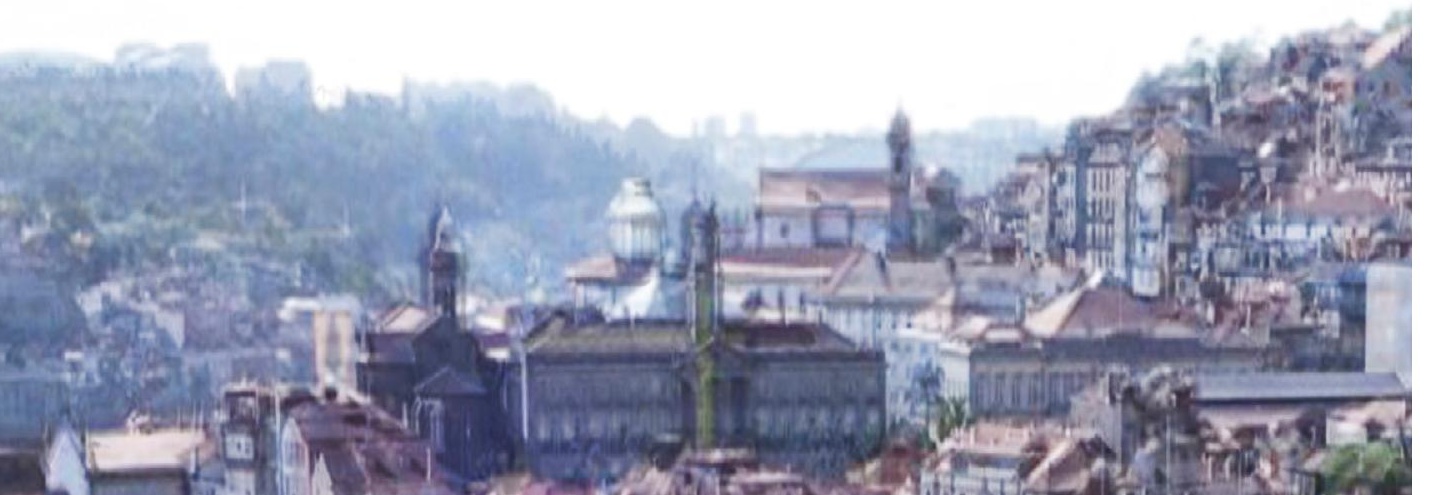

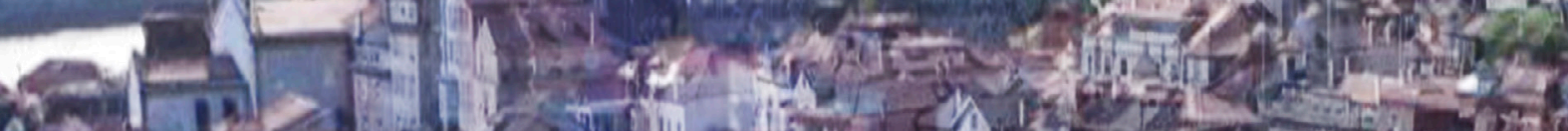

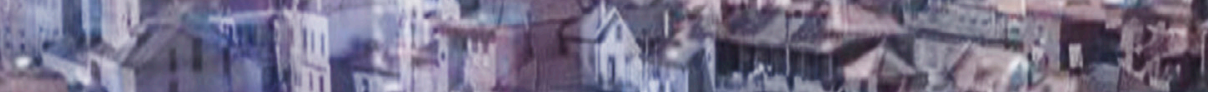
Apese ax)

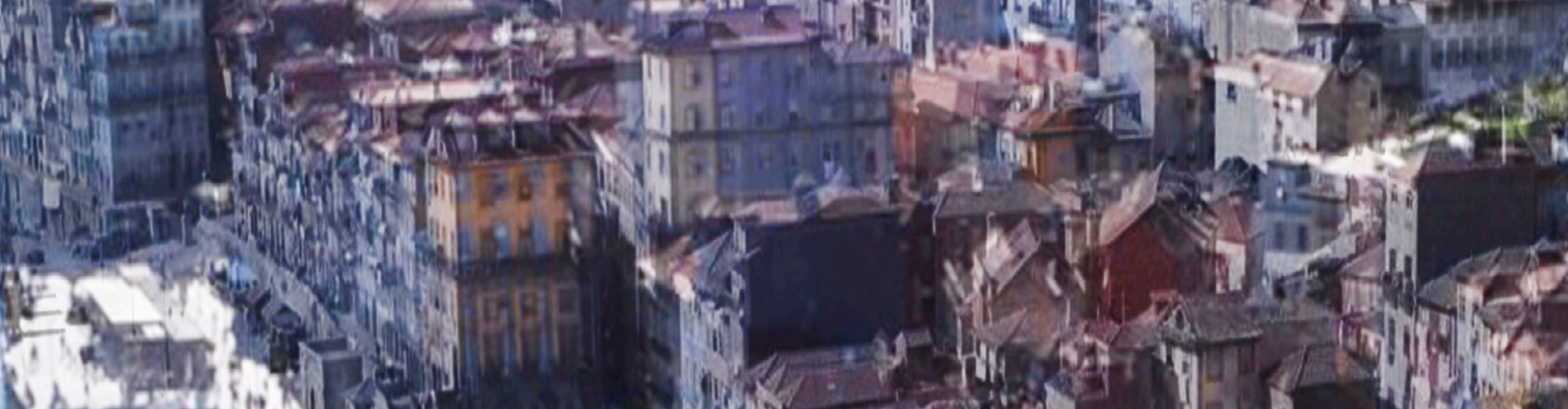

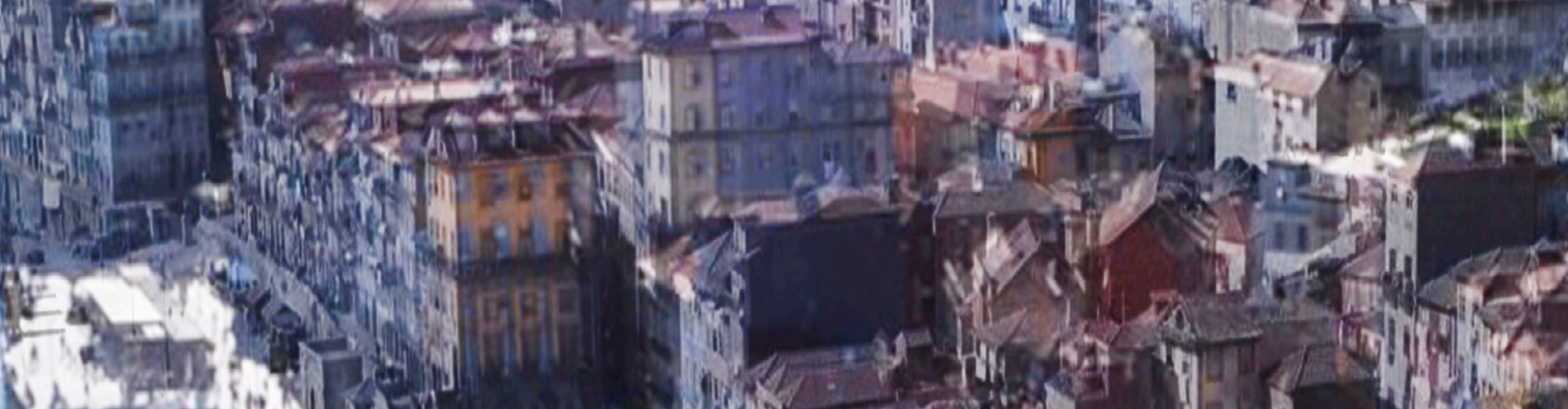

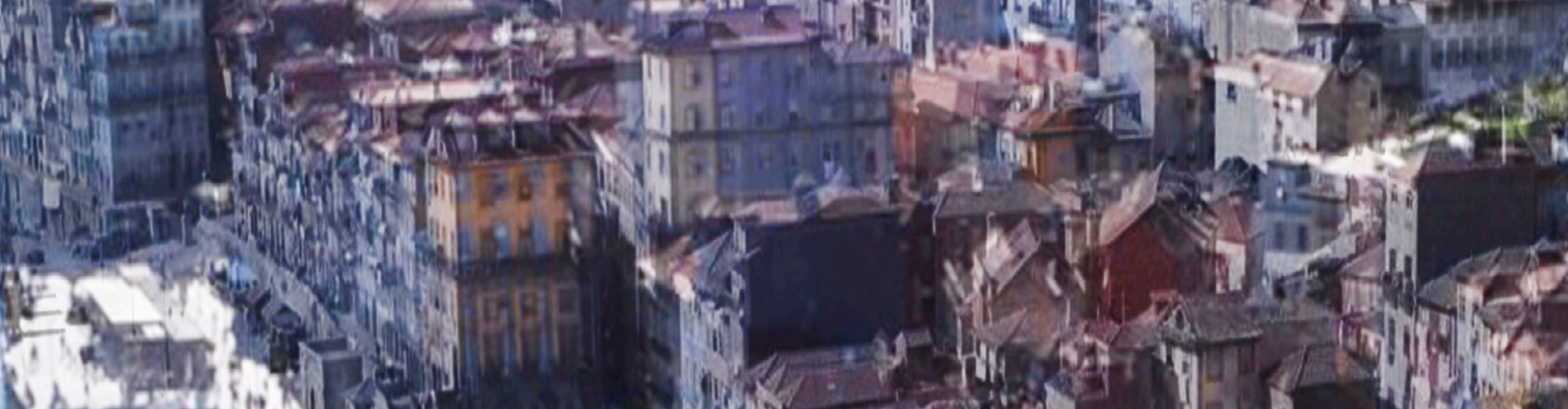

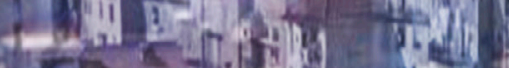

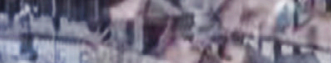

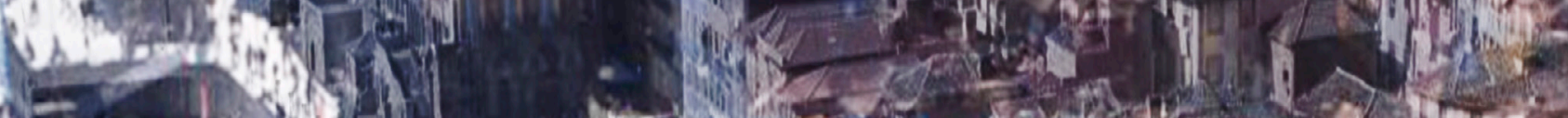

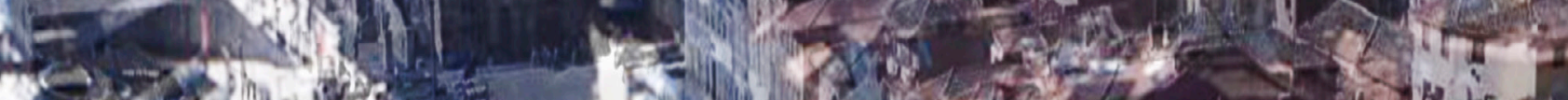

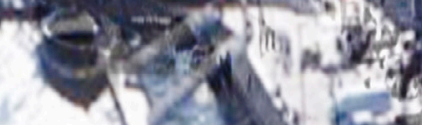

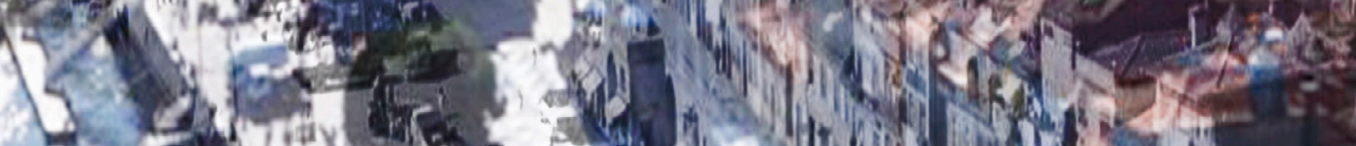

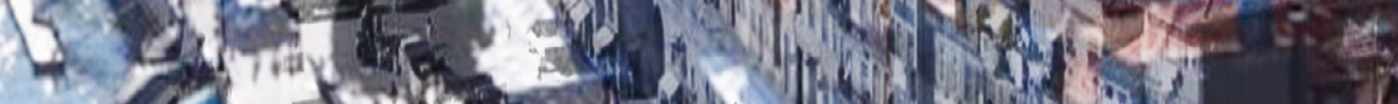

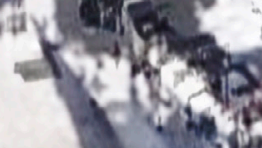

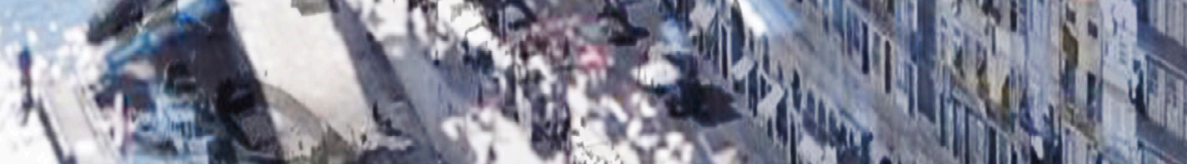

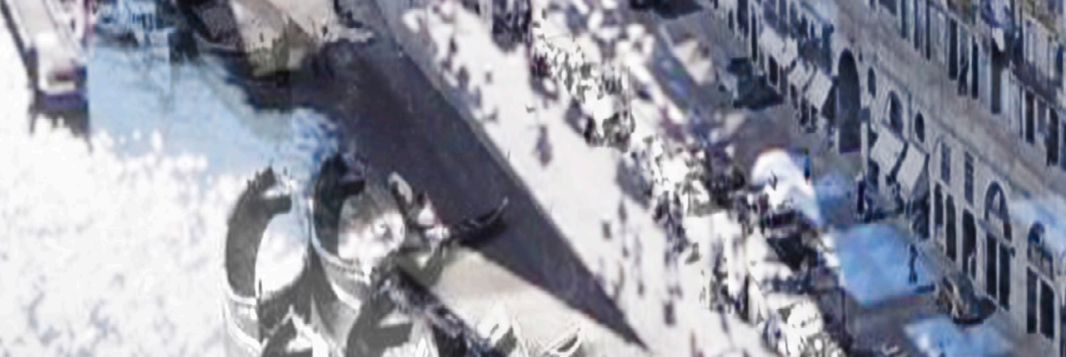

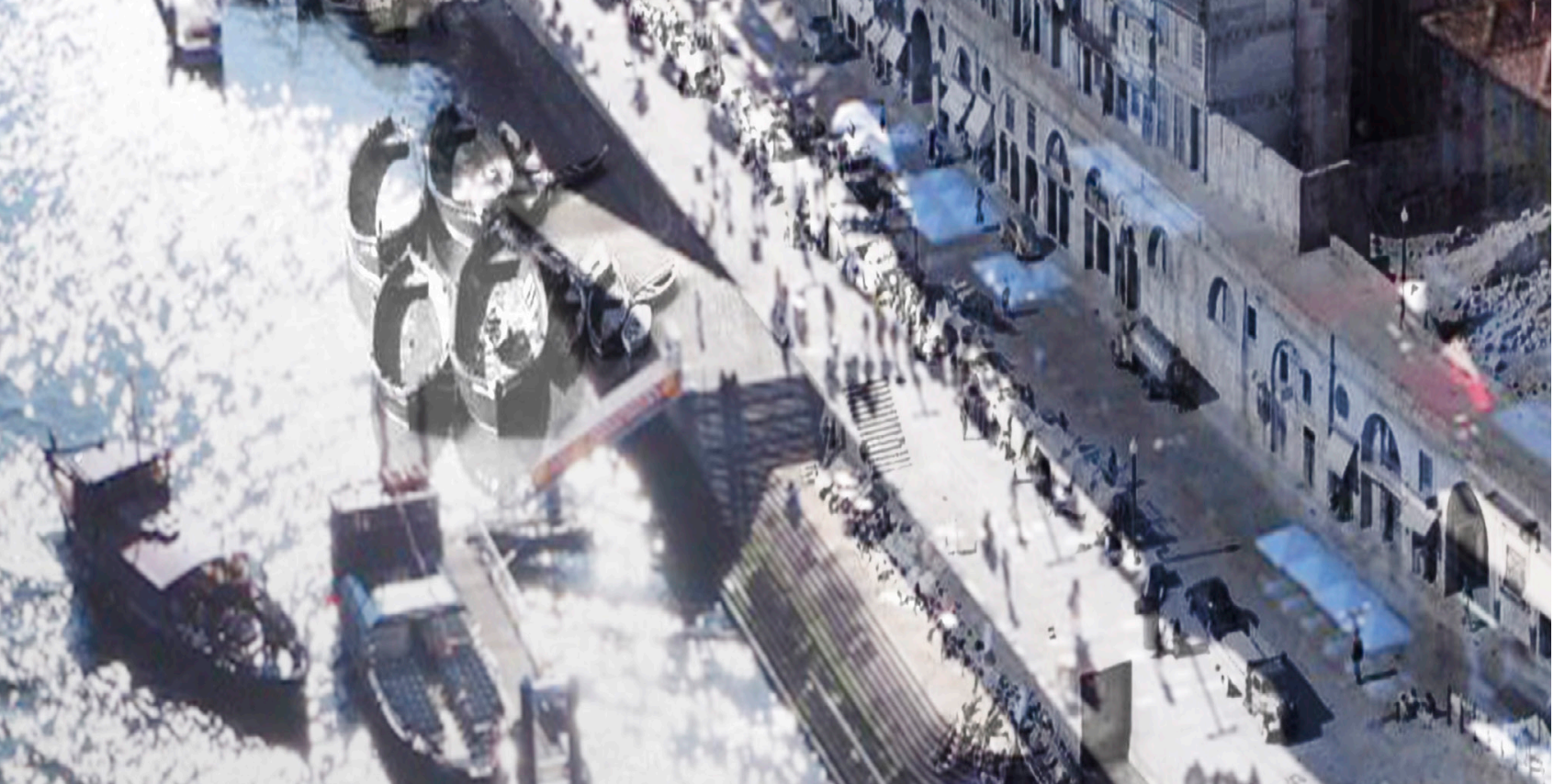




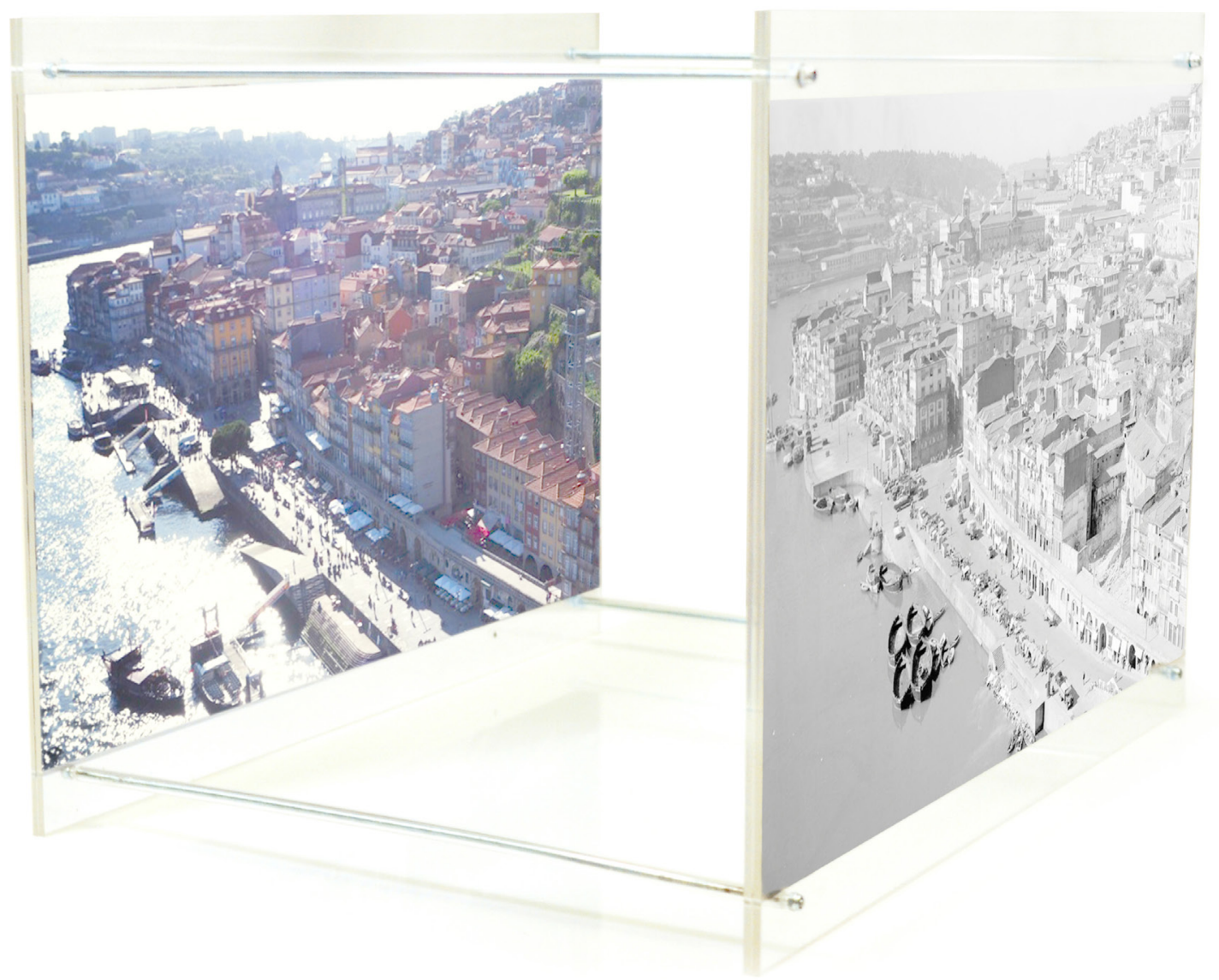

SERIE CAJA DE HISTORIAS 13

Cas Amarella Porto

Fotografía

Metacrilato y acetato

$42 \times 30 \times 30 \mathrm{~cm}$

Cas Amarella Porto

Fotografia

Metacrilato e acetato

$42 \times 30 \times 30 \mathrm{~cm}$ 


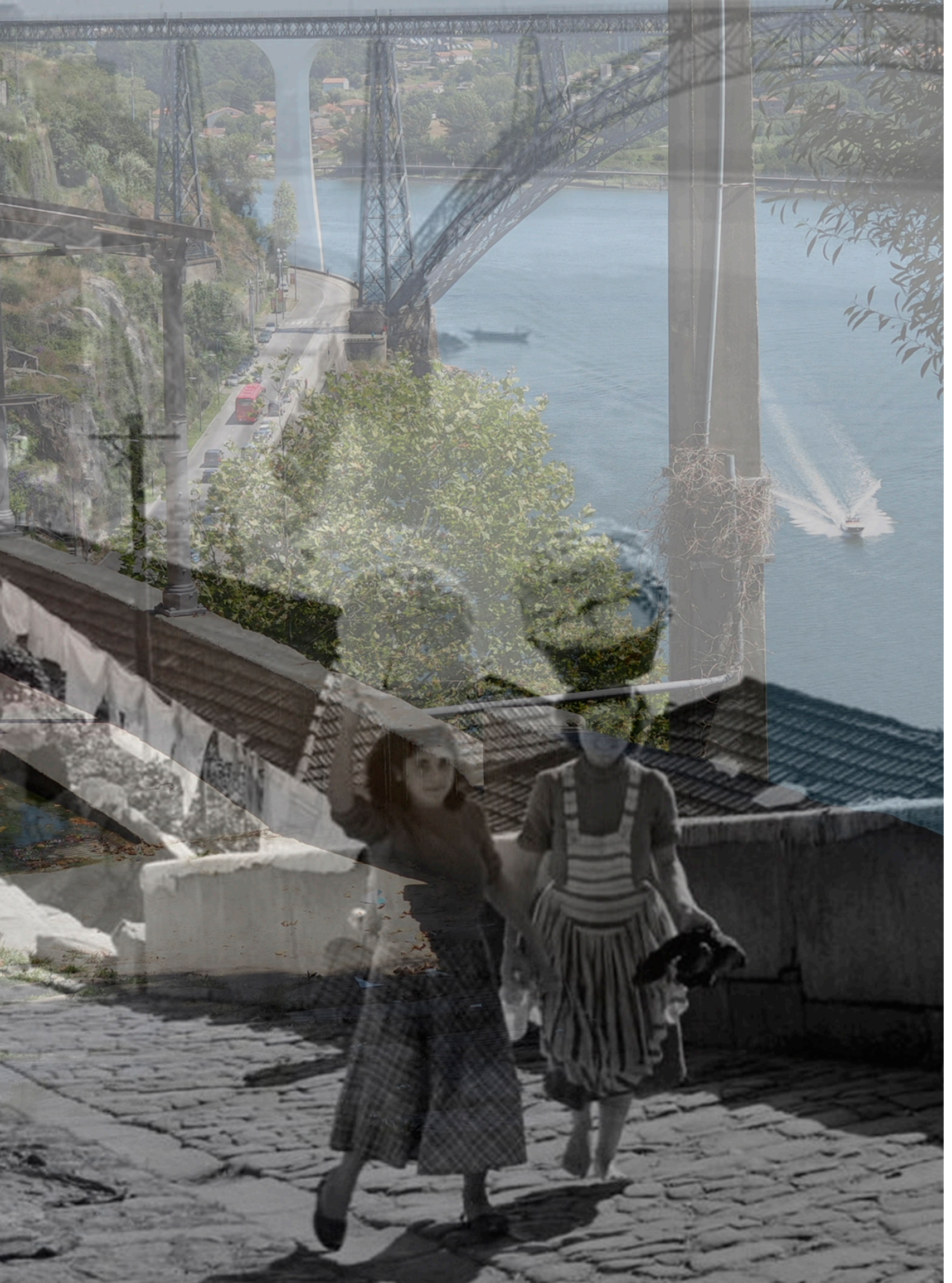




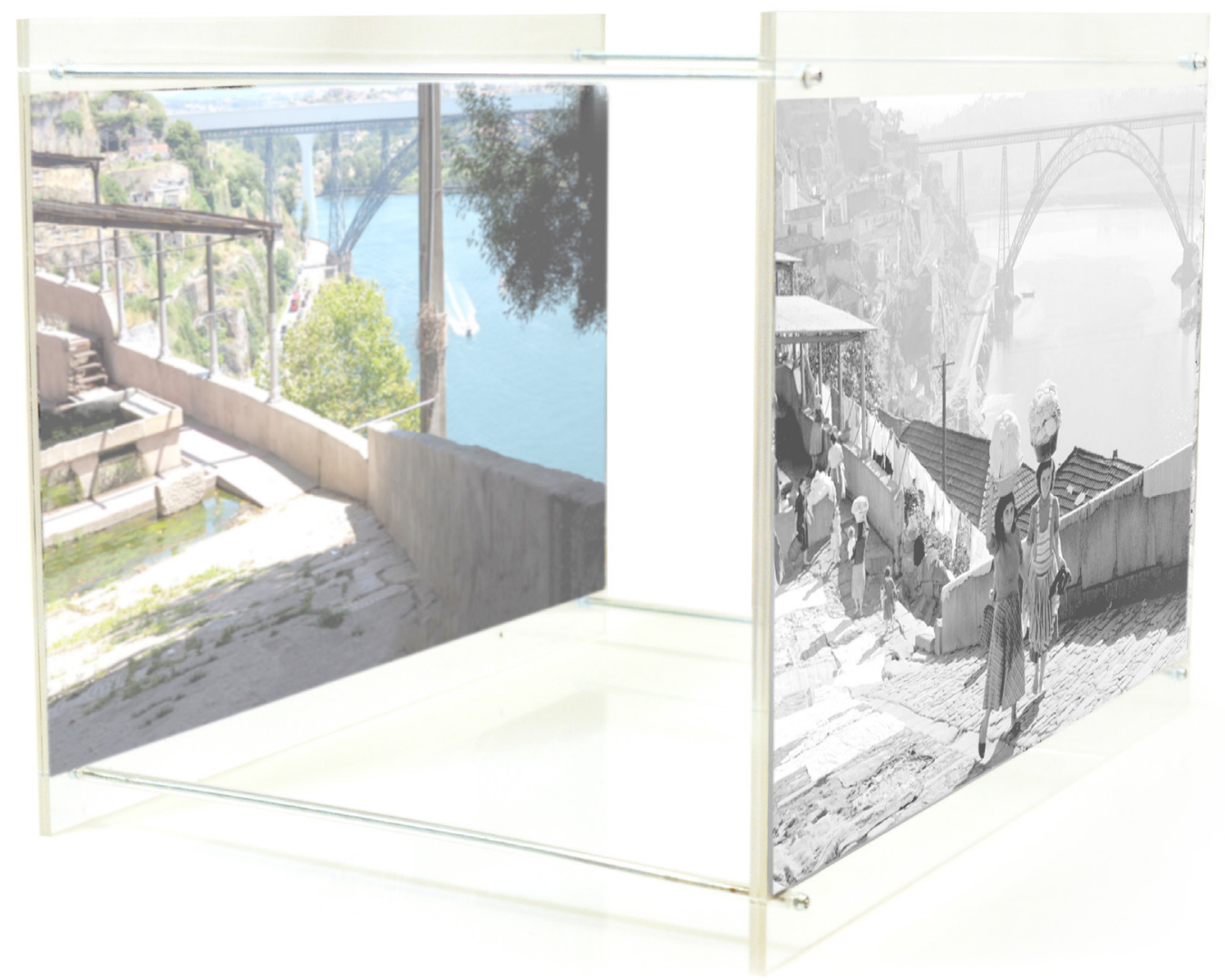

SERIE CAJA DE HISTORIAS 14

Passeio das Fontainhas Porto

Fotografía

Metacrilato y acetato

$42 \times 30 \times 30 \mathrm{~cm}$

Passeio das Fontainhas Porto

Fotografia

Metacrilato e acetato

$42 \times 30 \times 30 \mathrm{~cm}$ 

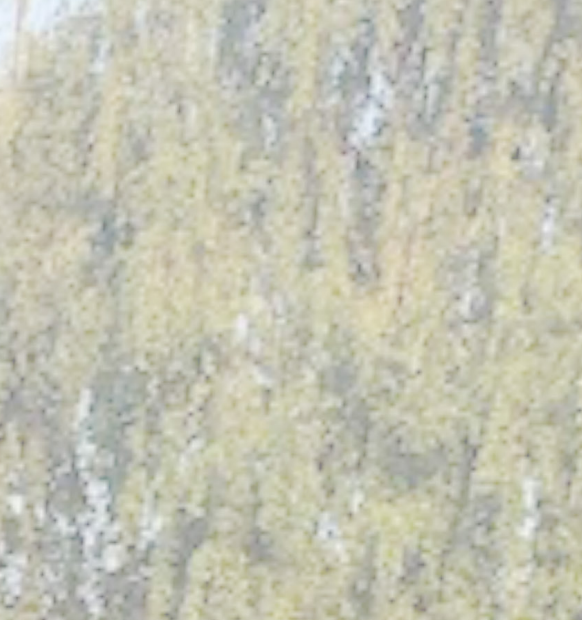

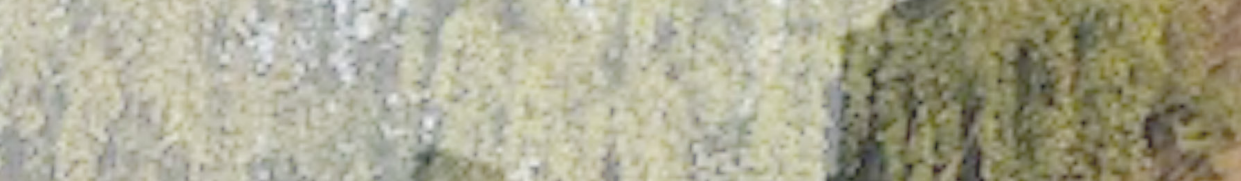

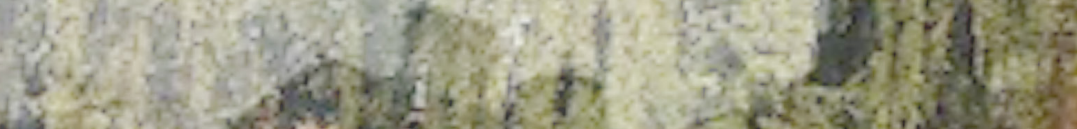
3)

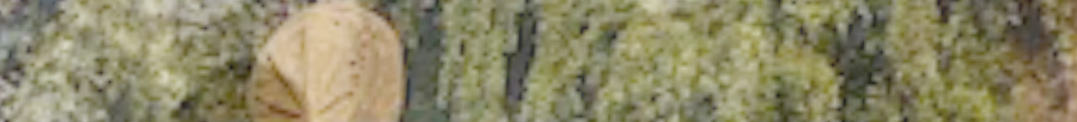

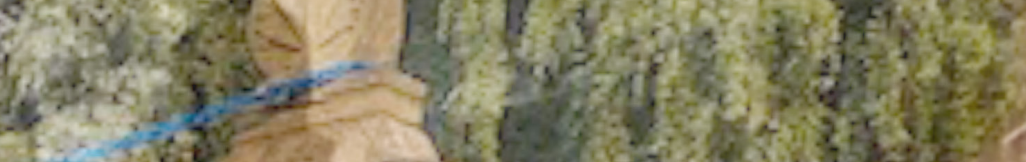

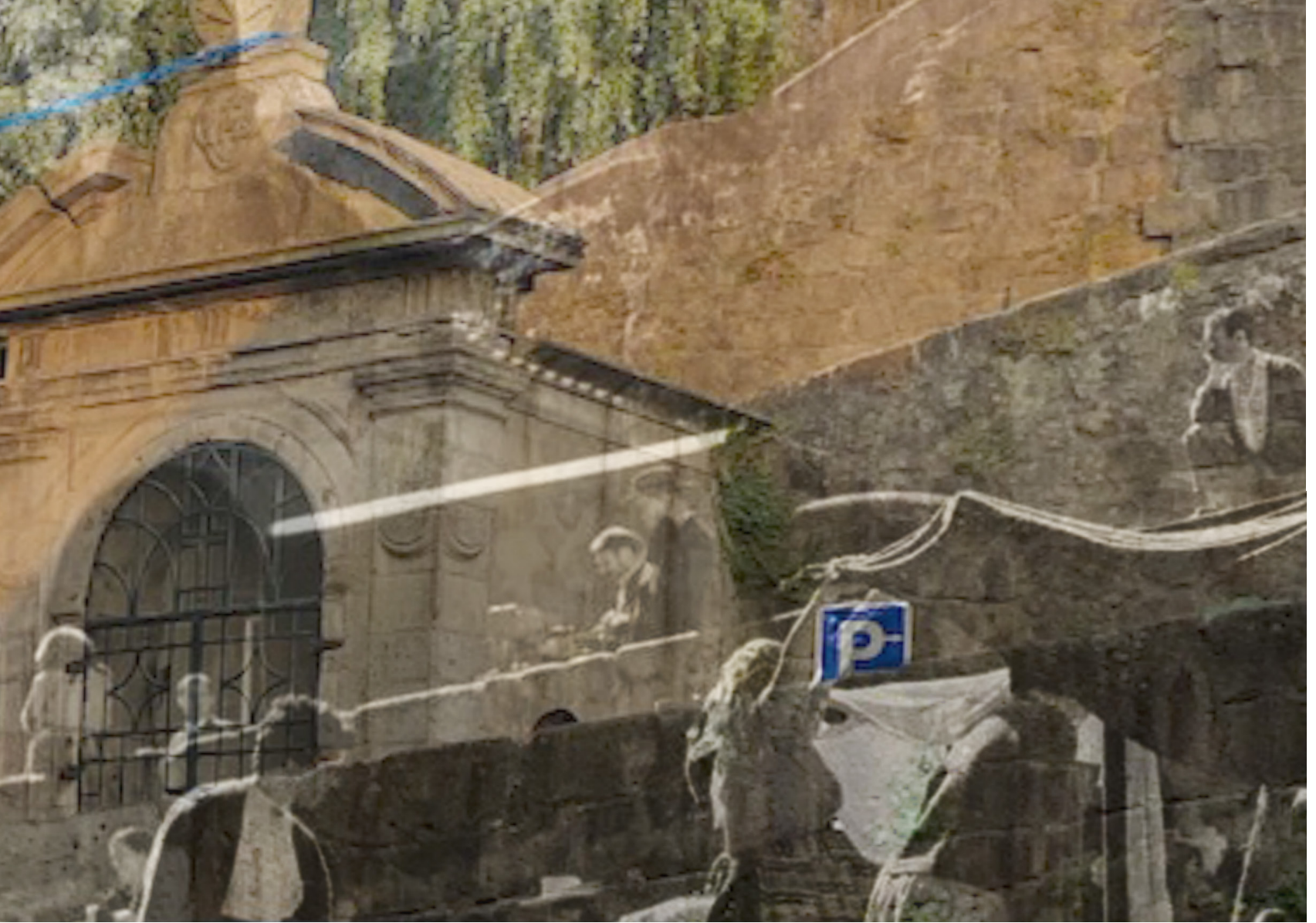




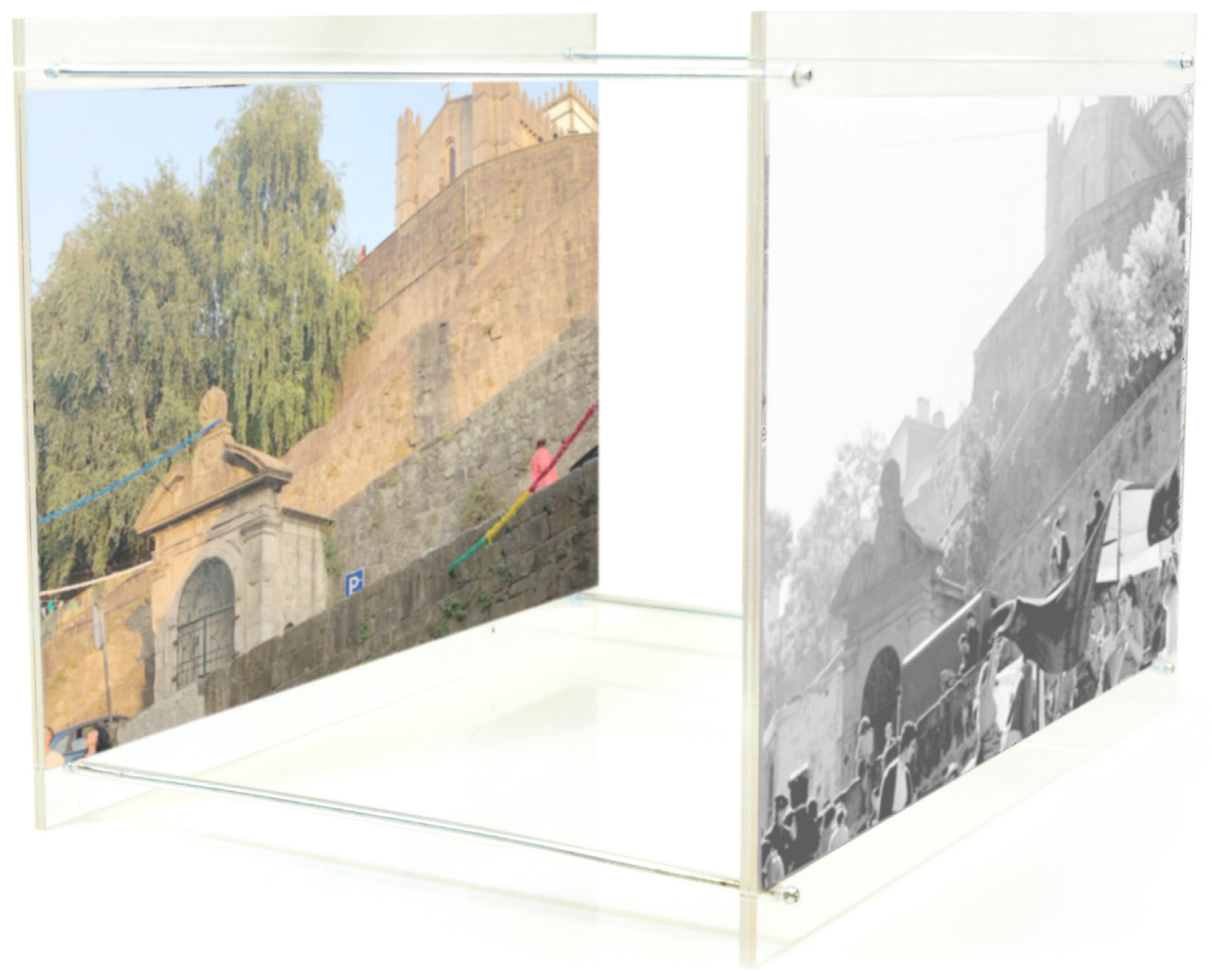

SERIE CAJA DE HISTORIAS 15

Mercado São Nicolau

Fotografía

Metacrilato y acetato

$42 \times 30 \times 30 \mathrm{~cm}$

Mercado de São Nicolau

Fotografia

Metacrilato e acetato

$42 \times 30 \times 30 \mathrm{~cm}$ 

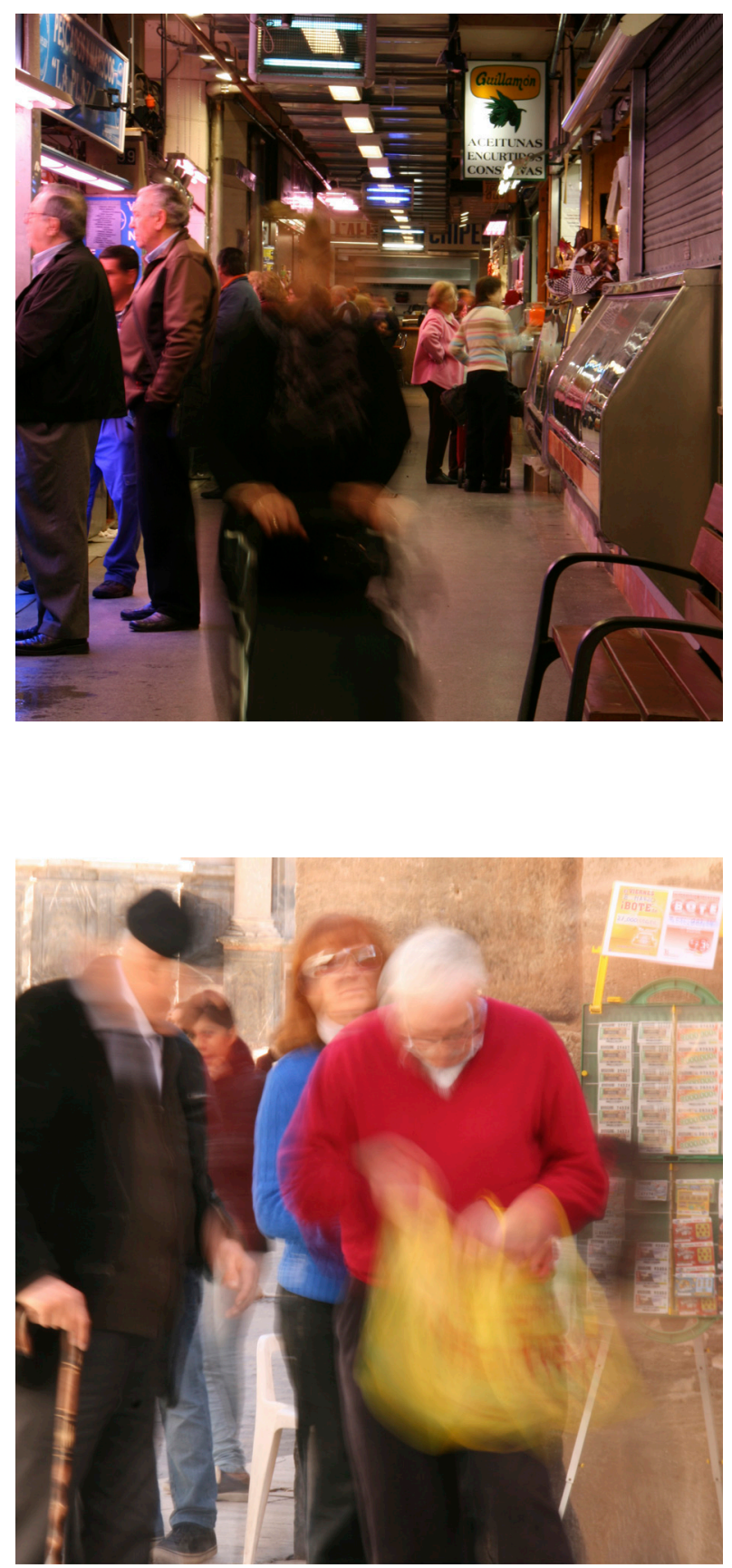

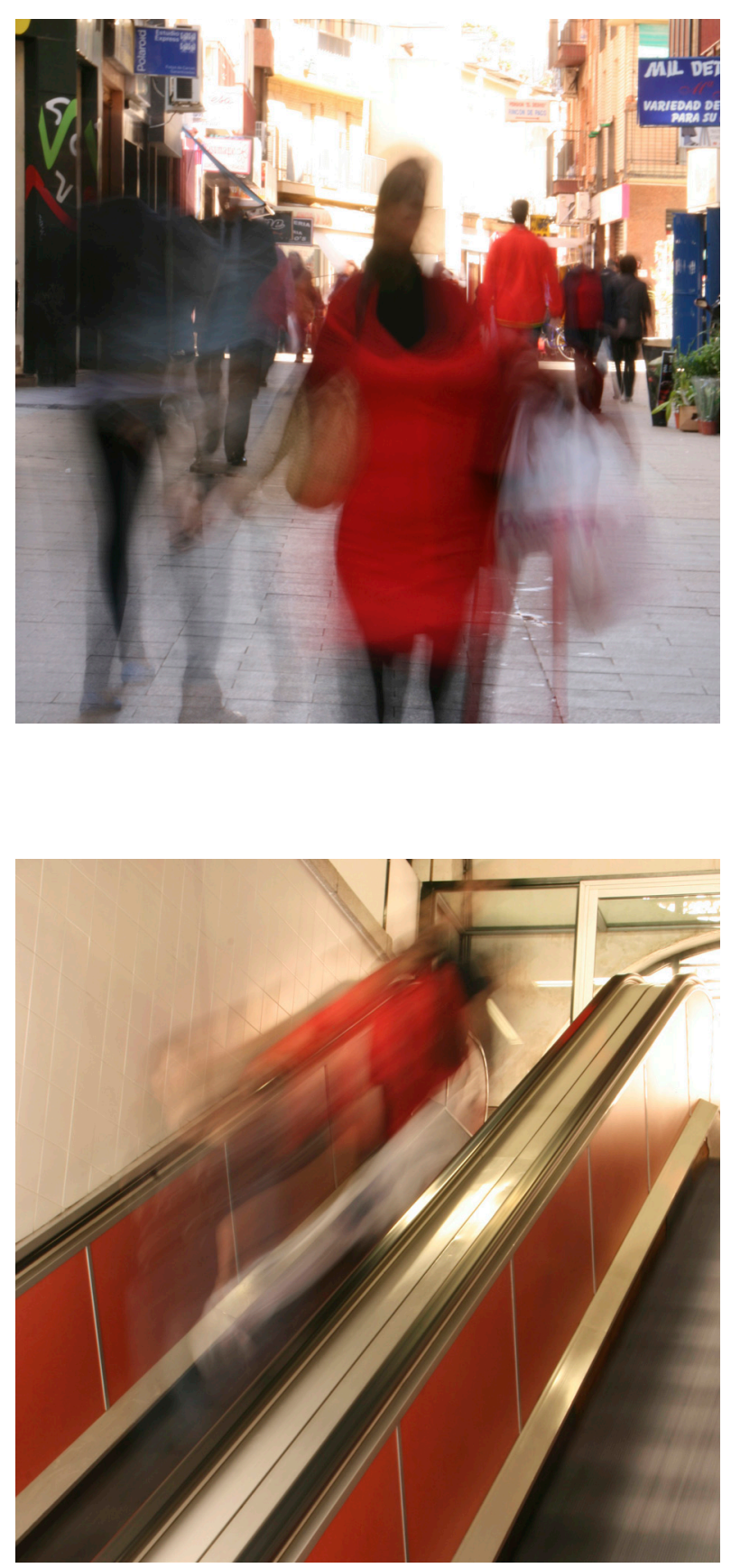

\section{SERIE REGISTROS AKÁSHICOS (2016)}

\section{4 fotografías}

Papel fotográfico brillo (enmarcado)

40 x $40 \mathrm{~cm}$ c.u.

4 fotografias

Papel fotográfico brilhante (emoldurado)

40 x $40 \mathrm{~cm}$ c.u. 


\section{Luz Bañón}

Murcia (España) 1969

Luz Bañón, seudónimo de María Luz Ruiz Bañón. Artista multidisciplinar murciana que experimenta su trabajo artístico en disciplinas como la pintura, la fotografía, la escultura o la videoinstalación. Licenciada en Bellas Artes por la Facultad de Murcia y Técnico Superior en Artes Plásticas y Diseño en Artes Aplicadas a la Escultura por la Escuela de Arte de Murcia en España, recibiendo el primer premio extraordinario de la Región de Murcia otorgado por la Consejería de Educación y Universidades en esta especialidad. Actualmente es contratada de investigadora predoctoral FPU del Ministerio de Ciencia, Innovación y Universidades de España en la Facultad de Bellas Artes de la Universidad de Murcia (España), donde trabaja como profesora en el área audiovisual. En los últimos años, ha realizado varias exposiciones individuales en España, y ha participado en numerosas exposiciones colectivas, festivales de arte y colaboraciones artísticas tanto en España como en diferentes ciudades de Europa como Venecia, Londres, Viena, Ámsterdam, Växjö o Leeds. En el último año ha realizado estancias de investigación tanto en Oporto como en Ámsterdam. Comprometida con la investigación, trabaja en la relación espacio-tiempo-arte a través de diferentes disciplinas, pero especialmente desde el video arte y la videoinstalación.
Luz Bañón, pseudónimo de María Luz Ruiz Bañón. Artista multidisciplinar Murciana que desenvolve trabalho artístico em disciplinas como pintura, fotografia, escultura ou video-instalação. Licenciada em Belas Artes pela Faculdade de Belas Artes da Universidade de Murcia. Técnica Superior em Artes Plásticas e Design em Artes

Aplicadas à Escultura pela Escola de Arte de Murcia, em Espanha, recebendo o primeiro prémio extraordinário da Região de Murcia concedido pela Consejería de Educación y Universidades, nesta especialidade. Na actualidade está contratada como investigadora pre-doctoral FPU do Ministerio de Ciencia, Innovación y Universidades de España na Faculdade de Belas Artes da Universidade de Murcia, onde colabora como professora da área do audiovisual. Nos últimos anos, realizou várias exposições individuais em Espanha, e participou de várias exposições coletivas, festivais de arte e colaborações artísticas na Espanha e em diferentes cidades europeias como Veneza, Londres, Viena, Amsterdão, Växjö ou Leeds. No último ano tem realizado estadias de investigação tanto no Porto, no I2ADS/ FBAUP, como em Amsterdão, com ASCA. A sua investigação desenvolve-se ao redor das relações espaço-tempo-arte através de diferentes disciplinas, mas especialmente da videoarte e da video-instalação. 


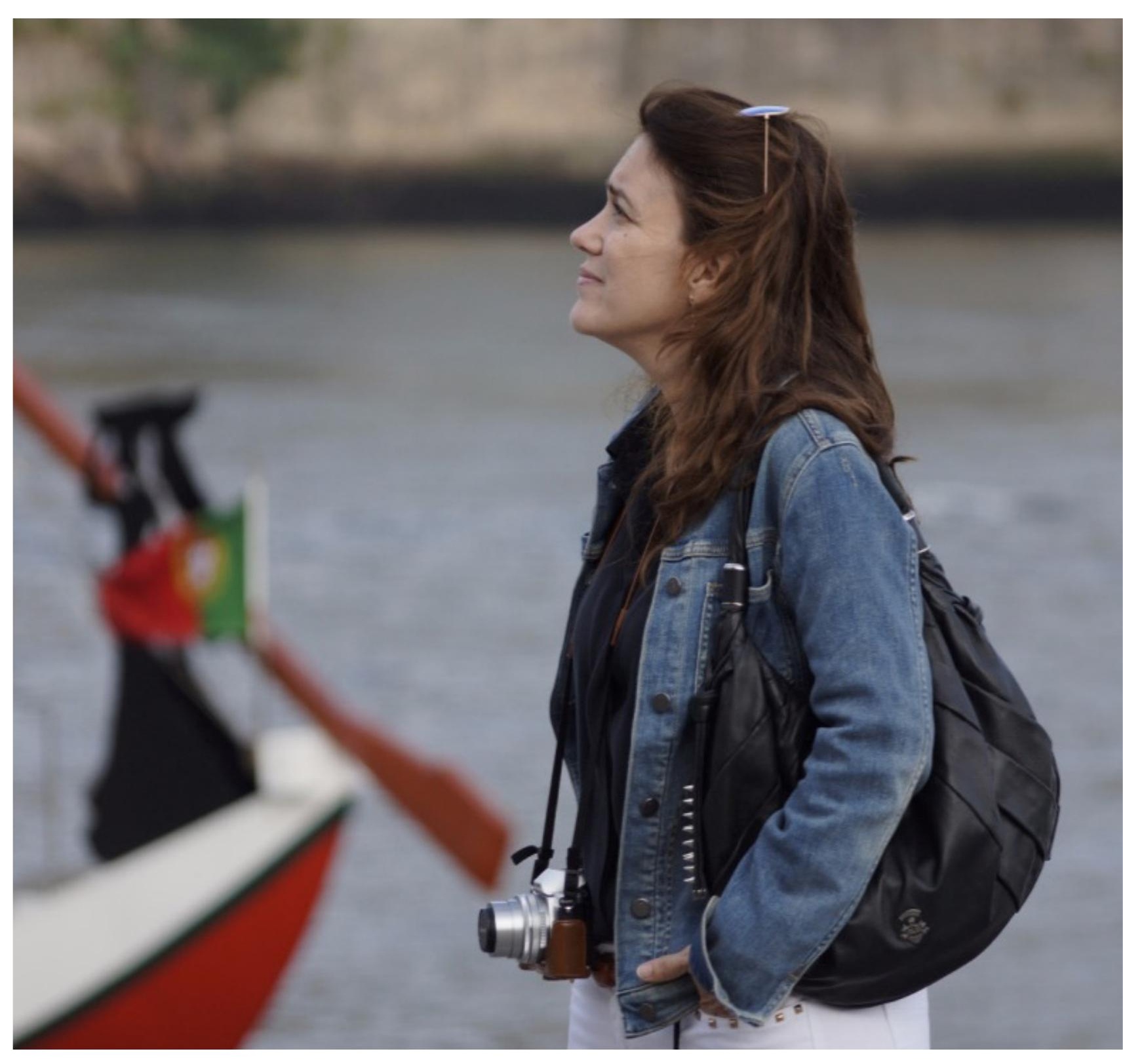


Domingos Loureiro

http://orcid.org/0000-0002-

5317-6726

Nasceu em Valongo em 1977. Doutorado em Arte e Design pela Universidade Porto.

Professor Auxiliar na

Faculdade de Belas Artes da Universidade do Porto, no Departamento de Artes Plásticas- Pintura. Coordenador da Secção da Pintura na FBAUP. Investigador integrado e foi membro da Direção (2017-19) do Instituto de Investigação em Arte, Design e Sociedade. Integra o Projecto Bases Conceptuais da Investigação em Pintura (2014-19). Organização do ICOCEP International Congress on Contemporary European Painting. (2017, 2019); Organização das 2as Jornadas de Arte e Design, 2017, entre outros eventos de natureza científica.

Artista plástico presente em exposições e coleções em diversos países como Espanha, França, Inglaterra, Bélgica, Itália, Irlanda, EUA, Brasil, Japão, Alemanha, Canadá, Holanda e Portugal, entre outros.

Autor e editor de diversos documentos científicos e académicos. Autor e orador em diversas conferências nacionais e internacionais, em Portugal e no estrangeiro.
Nacido en Valongo en 1977. Doctor en Arte y Diseño por la Universidad de Oporto. Profesor adjunto de la Facultad de Bellas Artes de la Universidad de Oporto, en el Departamento de Artes Plásticas - Pintura. Coordinador de la Sección de Pintura de la FBAUP. Investigador integrado y fue miembro de la Junta Directiva (2017-19) del Instituto de Investigación en Arte, Diseño y Sociedad. Intregra el proyecto Bases Conceptuales de la Investigación en Pintura (201419). Organizador de ICOCEP - Congreso Internacional de Pintura Europea Contemporánea. (2017, 2019); Organizador de las II Jornadas de Arte e Design, 2017, entre otros eventos de carácter científico.

Artista plástico presente en exposiciones y colecciones en varios países como España, Francia, Inglaterra, Bélgica, Italia, Irlanda, Estados Unidos, Brasil, Japón, Alemania, Canadá, Países Bajos y Portugal, entre otros.

Autor y editor de varios documentos científicos y académicos. Autor y ponente en varias conferencias nacionales e internacionales, en Portugal y en el extranjero.

\section{$M^{a}$ Victoria Sánchez Giner (Victoria Chezner)}

htpp://orcid.org/0000-00018142-2376

Nacida en Sant Joan d'Alacant (España) en 1969. Doctora en Bellas Artes con Mención Europea por la Universidad Politécnica de Valencia. Decana de la Facultad de Bellas Artes de la Universidad de Murcia. Profesora titular en el Departamento de Bellas Artes en la Facultad de Bellas Artes, y en el Máster de producción y gestión artística de la Universidad de Murcia. Cuenta con dos sexenios de investigación reconocidos por la CNEAI. Es miembro del Grupo de investigación ECCE HOMO de la Universidad de Murcia, y colaboradora en el grupo de investigación I2ADSNAD de la Universidade do Porto. Desde 2016, coordina el grupo de innovación docente internacional y multidisciplinar Arte en Construcción/ ecotono de la Universidad de Murcia. Ha participado en numerosos congresos internacionales, conferencias y seminarios, así como ha realizado múltiples publicaciones monográficas. Como artista visual ha realizado múltiples exposiciones colectivas así como individuales, entre las que destacan Del Jardí al Bosc (2020, Valencia),Tu Presencia (2019, Cartagena), Caminos de luz (2017, Mula), Siempre y Jamás (2016, Lorca), Campo a través (2010, Alcoy), Horizontes (2010, Buenos Aires, Argentina), Obzory (2010, Brno, República Checa), o Webscapes (2009, Valencia, Esp). 
Rute Rosas

http://orcid.org/0000-0001-

6281-8754

Nascida em Sant Joan d'Alacant (Espanha) em 1969. Doutoramento em Belas Artes com Menção Europeia pela Universidade Politécnica de Valência. Diretora da Faculdade de Belas Artes da Universidade de Múrcia. Palestrante no Departamento de Belas Artes da Faculdade de Belas Artes, e no Mestrado em Produção e Gestão Artística na Universidade de Múrcia. Conta com dois períodos de investigação de seis anos reconhecidos pela CNEAI. É membro do grupo de investigação ECCE HOMO da Universidade de Múrcia, e colabora com o Centro de Investigação I2ADS-NAD da Universidade do Porto. Desde 2016, coordena o grupo internacional e multidisciplinar de inovação pedagógica Arte en Construcción/ecotono na Universidade de Múrcia. Participou em numerosos congressos, conferências e seminários internacionais, bem como em múltiplas publicações monográficas. Como artista visual, realizou múltiplas exposições colectivas e individuais, incluindo Del Jardí al Bosc (2020, Valência), Tu Presencia (2019, Cartagena), Caminos de luz (2017, Mula), Siempre y Jamás (2016, Lorca), Campo a través (2010, Alcoy), Horizontes (2010, Buenos Aires, Argentina), Obzory (2010, Brno, República Checa), e Webscapes (2009, Valência, Espanha).
Nasceu em 1972 em Porto. Doutora em Arte e Design: Artes Plásticas - Escultura. Mestre em Arte Multimédia. Professora do Departamento de Belas Artes da Faculdade de Belas Artes da Universidade do Porto (FBAUP). Na FBAUP criou as disciplinas de Têxteis Construídos, Arte e Espaço e Cenografia, da LAP. É coordenadora científica da Área de Escultura do Mestrado em Artes Plásticas (MAP-E), membro da comissão Científica da Licenciatura em Artes Plásticas (LAP), membro do Conselho Científico e do Conselho de Representantes da FBAUP, entre outros cargos oficiais, além das atividades letivas e enquanto orientadora de mestrados e doutoramentos. $\mathrm{Pu}-$ blicou textos e artigos, e seu trabalho é mencionado em várias publicações. E coautora com Sofia Ponte do Projeto de Investigação CEM - Corpo, Espaço, Matéria - FBAUP Artista Plástica - Escultora, realiza exposições individuais e coletivas. Também desenvolveu, colaborou e organizou inúmeros eventos, como: exposições coletivas; oficinas; cursos; palestras, masterclasses e conferências em vários países. Além disso, trabalhou no desenvolvimento e produção de cenografias e figurinos. Premiada e com múltiplas distinções, o seu trabalho está representado em inúmeras instituições e coleções particulares em Portugal, Espanha, Itália, Inglaterra, Canadá e Brasil.
Nacida en 1972 en Oporto. Doctora en Arte y Diseño: Artes Plásticas - Escultura. Máster en Arte Multimedia. Profesora del Departamento de Bellas Artes de la Facultad de Bellas Artes de la Universidad de Oporto (FBAUP). En la FBAUP creó las disciplinas de Textiles Construidos, Arte y Espacio y Escenografía, de LAP. Es coordinadora científica del Área de Escultura del Máster en Artes Plásticas (MAP-E), miembro del Comité Científico del Grado en Artes Plásticas (LAP), miembro del Consejo Científico y del Consejo de Representantes de la FBAUP, entre otros cargos oficiales, además de su actividad docente y como supervisora de másteres y doctorados. Ha publicado textos y artículos, y su trabajo se menciona en varias publicaciones. Es coautora con Sofia Ponte del proyecto de investigación CEM - Corpo, Espaço, Matéria - FBAUP

Artista plástica - Escultora, realiza exposiciones individuales y colectivas, y colabora y organiza numerosos eventos como: exposiciones colectivas; talleres; cursos; charlas, clases magistrales y conferencias en varios países. Además, ha trabajado en el desarrollo y la producción de escenografías y vestuario. Premiada y con múltiples distinciones, su obra está representada en numerosas instituciones y colecciones privadas de Portugal, España, Italia, Inglaterra, Canadá y Brasil. 
Jesús Segura Cabañero

htpp://orcid.org/0000-0003-

3708-4140

Nacido en Cuenca en 1967, reside actualmente en Murcia. Doctor en Bellas Artes por la Universidad de Castilla la Mancha. Profesor titular en el Departamento de Bellas Artes en la Facultad de Bellas Artes de la Universidad de Murcia, y Vicedecano de Cultura, Empresa y Empleabilidad. Profesor en el Máster Internacional de Estudios Visuales del Centro de Estudios Visuales, el Máster de Gestión Cultural y el Máster de producción y gestión artística en la Universidad de Murcia. Cuenta con dos sexenios de investigación y uno de transferencia reconocidos por la CNEAI. Investigador principal en el proyecto HAR2015-64106-P: El espacio articulado. Miembro del Grupo de Investigación de excelencia E028-06: Estudios Visuales: Imágenes, Textos, Contextos de la UMU. Ha participado en numerosos congresos internacionales, conferencias y seminarios, así como ha realizado múltiples publicaciones monográficas. Artista visual presente en múltiples exposiciones monográficas y colectivas como la Bienal de Venecia, el ISCP de Nueva York, el CENART (México), MNCARS (Museo Nacional de Arte Reina Sofía), la Fundación La Caixa y Fundación Miró, entre otros.
Nascido em Cuenca em 1967, vive e trabalha actualmente em Múrcia. Doutorado em Belas Artes pela Universidade de Castilla la Mancha. Professor no Departamento de Belas Artes da Faculdade de Belas Artes da Universidade de Múrcia, e Vice-Diretor para a Cultura, Empresa e Empregabilidade. Professor no Mestrado Internacional em Estudos Visuais no Centro de Estudos Visuais, no Mestrado em Gestão Cultural e no Mestrado em Produção e Gestão Artística na Universidade de Múrcia. Tem duas bolsas de investigação de seis anos e uma bolsa de transferência reconhecida pela CNEAI. Investigador principal no projecto HAR2015-64106-P: El espacio articulado. Membro do Grupo de Investigação de Excelência E028-06: Estudos Visuais: Imagens, Textos, Contextos da UMU. Participou em numerosos congressos, conferências e seminários internacionais, bem como em muitas publicações monográficas. Artista visual presente em muitas exposições individuais e colectivas tais como a Bienal de Veneza, o ISCP em Nova Iorque, CENART (México), MNCARS (Museo Nacional de Arte Reina Sofía), Fundación La Caixa e Fundación Miró, entre outras.
Toni Simó Mulet

htpp://orcid.org/0000-00020917-9938

Nacido en Altea (Valencia) en 1969. Doctor en Bellas Artes por la Universidad Politécnica de Valencia. Profesor titular en la Facultad de Bellas Artes de la Universidad de Murcia en el Departamento de Bellas Artes y Vicedecano de Estudios. Profesor en el Máster Internacional de Estudios Visuales del Centro de Estudios Visuales, el Máster de Gestión Cultural y el Máster de producción y gestión artística en la Universidad de Murcia. Cuenta con un sexenio de investigación reconocido por la CNEAI. Investigador colaborador en el proyecto de Excelencia Har2015-64106-P "El espacio articulado: contextualizaciones en el arte contemporáneo, espacialidades y temporalidades en la producción artística actual" de la UMU. Ha participado en numerosos congresos internacionales, conferencias y seminarios, así como ha realizado múltiples publicaciones monográficas. Realizó una estancia internacional con beca en el Goldsmith's College de Londres. Su trabajo de investigación, tanto teórico como de producción artística, está basado en la escultura expandida, el espacio, el tiempo y la imagen hibridando los sistemas discursivos de lo contextual y lo social. 


\section{Luís Fortunato Lima}

Nasceu em Altea (Valência) em 1969. Doutorado em Belas Artes pela Universidade Politécnica de Valência. Professor no Departamento de Belas Artes da Faculdade de Belas Artes da Universidade de Múrcia e Vice-Diretor para os Estudos. Professor no Mestrado Internacional em Estudos Visuais no Centro de Estudos Visuais, no Mestrado em Gestão Cultural e no Mestrado em Produção e Gestão Artística na Universidade de Múrcia. Ele tem um período de investigação de seis anos reconhecido pela CNEAI. Investigador colaborador no projecto de excelência Har2015-64106-P “El espacio articulado: contextualizaciones en el arte contemporáneo, espacialidades y temporalidades en la producción artística actual" da UMU. Participou em numerosos congressos, conferências e seminários internacionais, bem como em numerosas publicações monográficas. Foi bolseira no Goldsmith's College, Londres, com uma bolsa de estudo internacional. O seu trabalho de investigação, tanto teórico como de produção artística, baseia-se na escultura expandida, espaço, tempo e imagem, hibridizando os sistemas discursivos do contextual e do social.
Nasceu em 1976 no Porto, cidade onde atualmente reside e trabalha.

Realizou a formação superior na Faculdade de Belas Artes da Universidade do Porto: licenciatura em Artes Plásticas-Pintura, Grau de Mestre em Práticas e Teorias do Desenho e Grau de Doutor em Arte e Design.

Desenvolve várias atividades em paralelo, nomeadamente a atividade artística, a docência no ensino superior -nas áreas artísticas do Desenho e da Pintura - e, ainda, a atividade de investigador, tendo publicado alguns artigos em revistas nacionais que se dedicam à reflexão sobre arte e imagem. Neste contexto realizou, também, várias comunicações públicas.
Nació en 1976 en Oporto, ciudad en la que actualmente vive y trabaja.

Realizó sus estudios superiores en la Facultad de Bellas Artes de la Universidad de Oporto: Licenciatura en Artes Plásticas-Pintura, Máster en Prácticas y Teorías del Diseño y Doctorado en Arte y Diseño.

Desarrolla varias actividades en paralelo, a saber, su actividad artística, la docencia en la enseñanza superior -en las áreas artísticas de Dibujo y Pintura- y también su actividad investigadora, habiendo publicado algunos artículos en revistas nacionales dedicadas a la reflexión sobre el arte y la imagen. En este contexto, también ha realizado varias presentaciones públicas. 


